\title{
Doymamış Koşullardaki Bir Şevin Yağış Etkisindeki Duraylılığını Etkileyen Parametrelerin İncelenmesi
}

\author{
Taha TAŞKIRAN ${ }^{1}$ \\ Ayşenur ASLAN FİDAN ${ }^{2}$
}

\section{ÖZ}

Çalışma kapsamında, yağışlı mevsimlerde şev duraysızlıklarının sıklıkla görüldüğü bir bölgede, doygun olmayan koşullardaki şevin duraylılığını etkileyen parametreler incelenmiştir. İncelenen parametreler; yağış yoğunluğu, yağış süresi, hidrolik iletkenlik ve şev eğimi olup; bölgeye ait gerçek yağış verilerini de içeren bir veri aralığı kullanılarak, yarıparametrik çalışma yapılmıştır. Bu şekilde şevin mevcut durumu ve parametre değişiminin etkisi aynı anda incelenebilmiştir. Yağışın etkisiyle oluşan emme basınçlarındaki değişim nümerik yöntemle elde edilmiştir. Şev analizlerinde negatif boşluk suyu basincindaki değişim dikkate alınarak, Bishop limit denge yöntemi kullanılmıştır. Analizler sonucunda belirli bir yüksekliğin üzerindeki şevlerde yağışlı dönemde görülen göçmelerin nedeni ve incelenen parametrelerin duraylılığa etkisi gösterilmiştir.

Anahtar Kelimeler: Doygun olmayan zeminler, sızma, şev duraylılığı.

\section{ABSTRACT \\ Investigation of the Parameters Affecting the Stability of Unsaturated Soil Slope Subjected to Rainfall}

In this study, impacts of some parameters on stability of unsaturated soil slope were investigated in a region, where slope instabilities were frequently observed during rainy seasons. The investigated parameters are rainfall (density and duration), hydraulic conductivity and slope inclination. A semi-parametric study was performed using a data including the actual rainfall data and soil properties of the region. Therefore, the current slope stability and effects of parameters were examined at the same time. The change in suction pressures due to rainfall was obtained by numerical method. Limit equilibrium method was used to analyze slope stability and considering decrease in shear strength of soil due to change

\footnotetext{
Not: Bu yazı

- Yayın Kurulu'na 28 Şubat 2018 günü ulaşmıştır. 01 Şubat 2019 günü yayımlanmak üzere kabul edilmiştir.

- 30 Kasım 2019 gününe kadar tartışmaya açıktır.

- https://dx.doi.org/10.18400/tekderg.399877

1 Dicle Üniversitesi İnşaat Mühendisliği Bölümü, Diyarbakır - taha@dicle.edu.tr https://orcid.org/0000-0001-8444-0094

2 Dicle Üniversitesi İnşaat Mühendisliği Bölümü, Diyarbakır, - aysenur.asln@gmail.com https://orcid.org/0000-0003-2166-5194
} 
in pore water pressure. Result of the analyses, the effects of parameters on slope stability and reasons of slope instabilities during rainy period were shown.

Keywords: Unsaturated soil, rain infiltration, slope stability.

\section{GİRIŞ}

Şev göçmeleri hem insan hayatı, hem de ülke ekonomisi açısından yıkıcı sonuçlar doğurmaktadır. Doygun olmayan zeminlerin yağışlı mevsimlerde şev duraylılığını kaybettiği tüm dünyada yaygın olarak görülmektedir[1]. Sızmanın doygun olmayan zemin üzerindeki etkilerinin anlaşılabilmesi için, öncelikle şev duraylılığı üzerindeki etkisi anlaşılmalıdır. Bu sebeple yağış etkisindeki şevlerle ilgili çok sayıda nümerik ve teorik çalışmalar yapılmıştır.

Oh ve Lu (2015) Kuzey Kore'de gerçekleşen iki farklı şev göçmesini, sonlu elemanlar yöntemi ve genişletilmiş limit denge yöntemini kullanarak örneklemişlerdir. Şev geometrisindeki, hidromekanik özelliklerdeki, kayma mukavemetindeki ve yağış miktarındaki farklılıklara rağmen; gerçekleşen iki farklı şev göçmesinin, modelin güvenlik sayısının birin altına düştüğü durumda meydana geldiğini belirtmişlerdir. Bu çalışma, yağış nedeniyle meydana gelebilecek şev duraysızlıklarının önceden belirlenmesinin mümkün olduğunu göstermiştir [2].

Oh ve Vanapalli (2010), sıkıştırılmış homojen dolgu şevin yağış etkisinde duraylılığını incelemişlerdir. Çalışma, doygun koşullarda kısa ve uzun dönem şev analizleri ile doygun olmayan koşullarda göllenme ve yağışın dikkate alındığı şev analizlerini içermektedir. Çalışma sonucunda sslak cephe üzerinde meydana gelen şev göçmelerinin düzlemsel değil, dairesel kayma yüzeyi şeklinde olduğu görülmüştür[3].

Kim ve arkadaşları (2006), Kore'de yaygın görülen iki farklı ayrışmış zeminde, yağış etkisi altında ıslak cephe derinliğinin değişimini araştırmışlardır. Çalışmada ıslak cephe derinliğini, zemin-su karakteristik eğrisini kullanan sonlu elemanlar yöntemi ve ayrıca Green-Ampt yöntemi ile tayin etmişlerdir. Çalışma sonucunda, ayrışmış zeminlerin şev duraylılığında ıslak cephe matrik emme büyüklüğünün etkin rol oynadığını belirlemişlerdir [4].

Cho ve Lee (2002), yağış etkisindeki şevlerin güvenlik sayısının elde edilmesi için yeni bir yöntem önermişlerdir. Sızmanın şev duraylılığına etkisini göstermek için sonlu elemanlar yöntemini kullanarak, iki boyutlu akım-deformasyon ilişkisini araştırmışlar ve daha sonra her sonlu elemanın düğüm noktasında elde ettikleri gerilme ve deformasyonları düzlem boyunca sürekli hale getirmişlerdir. Yağış süresince zemin matrik emmesinin azalması sonucu kayma mukavemetinde meydana gelen değişimi dikkate alarak, şev duraylılığını araştırmışlar ve optimizasyon tekniğiyle muhtemel kayma yüzeyini elde etmişlerdir. Yapılan çalışmada sızmanın şev duraylılığına olan tipik etkisiyle uyumlu sonuçlar elde etmişlerdir [5].

Siirt ili Veysel Karani beldesinde, yol çalışması sırasında 1/1 eğimle oluşturulan, özellikle $10 \mathrm{~m}$ ve üzeri yükssekliğe sahip şevlerde, yağış sonrasında meydana gelen duraysızlıklar nedeniyle mevcut çalışmanın yapılması gündeme gelmiştir. Şev duraysızlıkları yağış ile ilişsilendirilmiş ve sızmaya bağlı olarak güvenlik sayısında görülen azalmanın mertebesi araştırılmıştır. Bu kapsamda yarı-parametrik yöntem kullanılarak yağış yoğunluğunun, yağış 
süresinin, zemin geçirgenliğinin ve şev eğiminin sızmaya ve buna bağlı olarak bölgedeki şevlerin duraylılığına olan etkileri incelenmiştir.

Analizlerde şev geometrisi seçilirken; sıklıkla gözlemlenen şev duraysızlıklarından dolayı sınır değer olan $10 \mathrm{~m}$ yükseklik ve şev eğimi için ise yine yol uygulamalarında çoğunlukla tercih edilen 1/1 eğim dikkate alınmıştır. Ayrıca şev geometrisinin etkisi, farklı şev eğimleri kullanılarak yapılan analizlerle incelenmiştir.

Yağış yoğunlukları, belirlenen alanın yağış verileri elde edilerek ve zemin özellikleri ise deneylerden belirlenerek kullanılmıştır. Analizlerde, incelenen parametre dışındaki diğer tüm parametrelerde gerçek verilere bağlı kalınarak, parametrelerin duraylılığa etkisi daha gerçekçi şekilde elde edilmeye çalışılmıştır.

\subsection{Zemin-Su Karakteristik Eğrisi}

Emme basıncı doygun olmayan zeminin mühendislik özelliklerini etkileyen en önemli ve temel parametrelerden birisidir. Richards (1965) tarafından zemin suyundaki bu bağımsız enerjinin, zemin suyunun kısmi buhar basıncına bağlı olarak ölçülebileceği ortaya çıkarılmıştır [6].

Fredlund ve Morgenstern (1977) normal gerilmeyi ve matrik emmeyi doygun olmayan zeminin gerilme durum değişkenleri olarak ifade etmiş̧lerdir. Zeminin su içeriği, zeminde bulunan matrik emmenin bir fonksiyonudur [7]. Zeminin su içeriği ile emme basıncı arasındaki bu ilişki; her hacimsel su muhtevasına karşılık gelen emme basıncı gösterildiği; zemin-su karakteristik eğrisi olarak bilinen eğri ile ifade edilebilir [8]. Laboratuvar çalışmaları doygun olmayan zeminlerin özellikleri ile zemin-su karakteristik eğrisi arasında bir ilişki olduğunu göstermektedir [9]. Bu sebeple zemin-su karakteristik eğrisini tanımlamak oldukça önemlidir (Şekil 1).

Zemin-su karakteristik eğrisi 1slanma ve kuruma süreçlerinde farklı yol izler. Eğrinin en önemli parametreleri hava giriş değeri (AEV) ile rezidüel su içeriğidir. Hava giriş değeri, zemin boşluklarına havanın nüfuz ettiği matrik emmeyi ifade eder. Eğri üzerinde hava-giriş değerinin elde edilebilmesi için zeminin \%100 doygun olduğu noktadan ( $\Theta$ s), x-yatay eksenine paralel olacak şekilde bir doğru çizilir. Eğrinin birinci kırılma noktasından sonra gelen geçiş bölgesindeki doğru uzatılarak; paralel doğru ile kesiştirilir ve bu kesişim noktası hava giriş değerini, $\left(\mathrm{u}_{\mathrm{a}}-\mathrm{u}_{\mathrm{w}}\right)_{\mathrm{b}}$ verir (Şekil.1).

Rezidüel su içeriğinin eğri üzerinden elde edilebilmesi için eğrinin kuyruk kısm1 $10^{6} \mathrm{kPa}$ emme basıncını \%0 hacimsel su içeriğinde kesecek şekilde uzatılır. Bu doğru ile eğrinin geçiş kısmında kalan doğru kesiştirilerek, rezidüel hacimsel su içeriği elde edilir (Şekil 1).

\subsection{Sizma Teorisi}

Yağmur ya da sulama yoluyla zemin yüzeyinde oluşan suyun, zemine nüfuz etmesi süreci sızma olarak tanımlanır. Gelen su oranı, zeminin sızma oranını aşarsa; göllenme veya yüzey akışı oluşur [10]. Yağmur suyunun sızması, asılı su tablası oluşmasına veya yeraltı su seviyesinde yükselmeye neden olur ve sonuç olarak boşluk suyu basıncında bir artış veya zemin matrik emmesinde bir azalma meydana gelir [1]. 


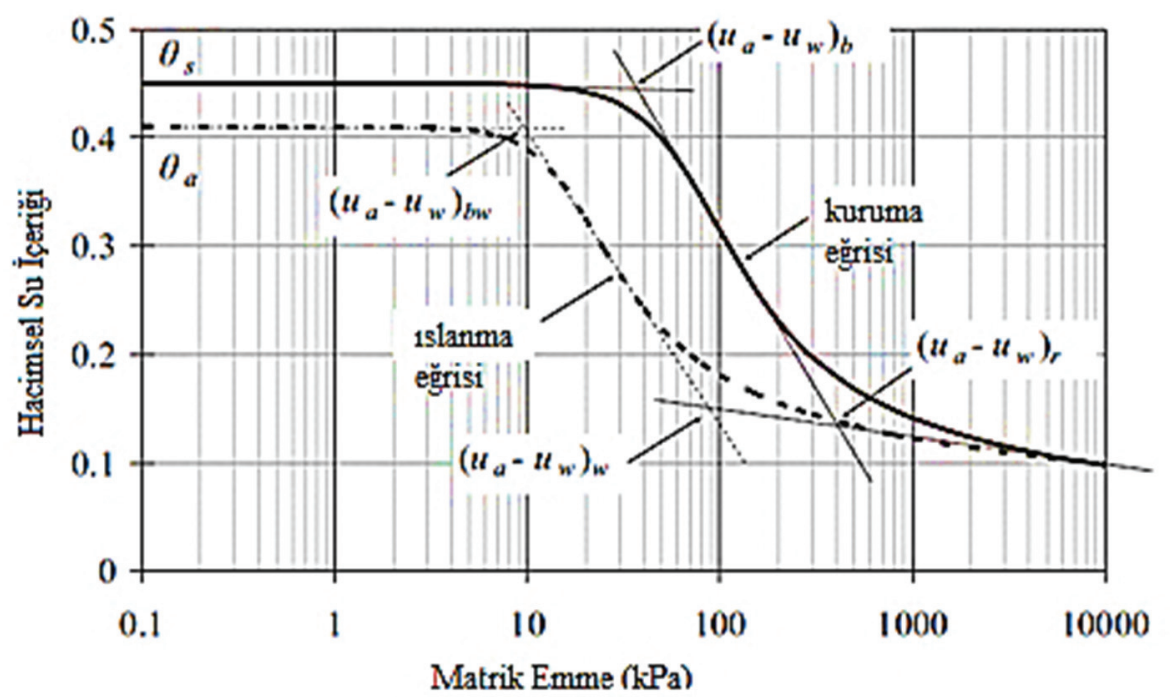

Şekil 1 - Genel zemin-su karakteristik eğrisi (Fredlund ve Xing 1994)

Sızma sürecini anlamak için birçok teorik çalışma yapılmıştır. Pradel ve Raad (1993), GreenAmpt (1911) eşitliğini temel alan bir denklem önermiştir [11]. Bu denklem yağış yoğunluğu ve süresini, zeminin hacimsel su içeriğini ve sslak cephe emme basıncı dikkate almaktadır. Belirli bir derinliğe $\left(\mathrm{z}_{\mathrm{w}}\right)$ kadar zeminin doygunlaşması için gereken süre;

$T=\frac{\mu}{k_{s}}\left[z_{w}-\psi \ln \left(\frac{\psi+z_{w}}{\psi}\right)\right]$

ile ifade edilmektedir. Denklemde; T yağış süresini, $\mu$ zeminin başlangıç ve doygun hacimsel su içerikleri arasındaki farkı, $\mathrm{k}_{\mathrm{s}}$ zeminin doygun haldeki geçirgenliğini, $\mathrm{z}_{\mathrm{w}}$ derinliği, $\Psi$ ise zeminin doygunlaşmadan hemen önce sahip olduğu negatif boşluk suyu basıncını ifade etmektedir.

Pradel ve Raad (1993), $z_{\mathrm{w}}$ derinliğine kadar zeminin doygunlaşması için; yağış yoğunluğunun (I), sızma oranından (v) daha büyük veya en azından eşit olması ve yağışın $\mathrm{T}_{\min }$ süresinden daha uzun sürmesi gerektiğini belirtmişlerdir. Sızma oranı;

$v=k_{s}\left(\frac{\psi_{f}+z_{w}}{z_{w}}\right)$

ile ifade edilmektedir. $T=T_{\min }$ ve $I_{\min }=v$ alarak, (1) ve (2) 'yi birleştirerek (3)'ü önermişlerdir.

$I_{\min }=\frac{\mu}{T_{\min }}\left[z_{w}-\psi \ln \left(\frac{\psi+z_{w}}{\psi}\right)\right]\left(\frac{z_{w}+\psi}{z_{w}}\right)$

Denklemde; $I_{\min }$ minimum yă̆ı̧s yoğunluğunu ve $T_{\min }$ ise sızmanın meydana gelmesi için gerekli olan asgari yağış süresini ifade etmektedir. 


\subsection{Doygun Olmayan Zeminlerin Kayma Mukavemetinin Belirlenmesi}

Doygun olmayan zeminlerin kayma mukavemeti, bağımsız gerilme durum değişkenleri ile ifade edilebilir. Gerilme durum değişkenlerinden herhangi iki tanesi kayma mukavemeti denklemi için kullanılabilir. $\left(\sigma-u_{a}\right)$ ve $\left(u_{a}-u_{w}\right)$ gerilme değişkenleri kullanılarak (4) elde edilmiştir [12].

$\tau=c^{\prime}+\left(\sigma-u_{a}\right) \tan \phi^{\prime}+\left(u_{a}-u_{w}\right) \tan \phi^{b}$

Denklemde $c$ 've $\phi$ ' sırasıyla efektif kohezyon ve efektif içsel sürtünme açısını, $\left(\sigma-u_{a}\right)$ net normal gerilmeyi, $\left(u_{a}-u_{w}\right)$ matrik emmeyi ve son olarak $\phi^{b}$ ise matrik emmeye bağlı olarak kayma mukavemeti artış miktarını gösteren açıyı belirtmektedir. Doygun olmayan zeminlerin kayma mukavemeti için önerilen denklem, doygun zeminlerin kayma mukavemeti denkleminin genişletilmiş halidir.

Fredlund ve arkadaşları (1978), doygun olmayan zeminlerin kırılma zarfını, matrik emmeye bağlı olarak ve kayma mukavemeti artış miktarını gösteren açıyı, $\phi^{b}$ sabit kabul ederek; doğrusal önermiştir [12]. Fakat yapılan birçok deneysel çalışma kırılma zarfının doğrusal olmadığını göstermektedir [13], [14], [15]. Bu nedenle $\phi^{b}$ açısının matrik emmeye bağlı olarak değiştiği düşünülmektedir.

Vanapalli ve ark. (1996) [16], doygun olmayan zeminin kayma mukavemetini belirlemek için, bir zemin-su karakteristik eğrisi boyunca farklı doygunluk derecelerinde su alanının değişimini tanımlayarak (5)'i önermişlerdir. Bu denklem ile her matrik emme değişimi için kayma mukavemeti belirlenebilir.

$\tau=c^{\prime}+\left(\sigma_{n}-u_{a}\right) \tan \phi^{\prime}+\left(u_{a}-u_{w}\right)\left[\left(\tan \phi^{\prime}\right)\left(\frac{\theta-\theta_{r}}{\theta_{s}-\theta_{r}}\right)\right]$

Denklemde; $\theta, \theta_{r}, \theta_{s}$ sırasıyla zeminin; hacimsel su içeriğini, rezidüel hacimsel su içeriğini ve doygun hacimsel su içeriğini ifade etmektedir.

\section{2. İNCELENEN ZEMININ ÖZELLIKKLERI}

Çalışma için gerekli zemin parametrelerinin en önemlileri; zeminin geçirimliliği, kayma mukavemeti ve zemin su karakteristik eğrisidir. Çalışmada şev analizlerine veri sağlamak amaciyla kullanılan numuneler Bitlis-Zagros Kenetlenme Kuşağı üzerinde bulunan, Siirt ili Baykan ilçesi Veysel Karani beldesinde; yol çalışması yapılan alandan alınmış olup; Şelmo Formasyonu, Ziyaret Karışığı, Baykan Karışığı ve Guleman Ofiyoliti'nden oluşmaktadır. Bu nedenle incelenen alan oldukça heterojen olup, bölgede bulunan başlıca zemin "fisürlü ofiyolitik kil" olarak adlandırılmaktadır. İnceleme alanındaki gözlemlerin sonucu olarak, yaklaşık 10 m yüksekliğindeki şevlerin, yağışın yüksek olduğu dönemlerde, yağış sırasında veya sonrasında ve özellikle yağışın belirli miktarı aştığı durumlarda, duraylılığını kaybettiği görülmüştür. Yağışın şev duraylılığında meydana getirdiği etkilerin açık şekilde görülebilmesi için analizlerde, bu bölgedeki zemine ait özellikler ve gerçek yağış verileri kullanılmıştır. 
Zeminin heterojen yapısından dolayı, alınan numunelerde zemin türünün geniş bir yelpazede değiştiği görülmektedir (Tablo 1). Bu nedenle zemin özellikleri Tablo 1'de değişim aralığı şeklinde sunulmuştur.

Tablo 1 - Zemine ait indeks/fiziksel özellikler

\begin{tabular}{ll}
\hline Zemin İndeks/Fiziksel Özellikleri & Değişim Aralığı \\
\hline Doğal Su İçeriği (\%) & $21.37-25.83$ \\
Likit Limit (\%) & $22.62-62.15$ \\
Plastik Limit (\%) & $15.74-26.51$ \\
Plastisite İndisi (\%) & $6.88-35.64$ \\
\#4 Elekte Kalan (\%) & $0.16-48.74$ \\
\#200 Elekten Geçen (\%) & $31.25-90.05$ \\
Özgül Ağırlığı & $2.721-2.748$ \\
Doğal Birim Hacim Ağırlığı (kN/m3) & $18.35-20.11$ \\
Grup Sembolü & $\mathrm{CL}, \mathrm{CL}-\mathrm{ML}, \mathrm{CH}, \mathrm{GC}$ \\
Permeabilite Katsayısı (m/sn) & $1 \times 10^{-7}-6 \times 10^{-7}$ \\
\hline
\end{tabular}

Çalışma alanından alınan numuneler üzerinde sınıflandırma için yıkamalı elek analizleri, hidrometre, likit limit ve plastik limit deneyleri ile özgül ağırlık deneyleri TS1900-1'e uygun olarak yapılmıştır [17]. Zemine ait permeabilitenin belirlenmesi için sahada, sondaj kuyularında yapılan basınçlı su testi sonuçları kullanılmıştır. Çalışmada hem ölçülen geçirimlilik $\left(5 \times 10^{-7} \mathrm{~m} / \mathrm{sn}\right)$ kullanılarak, hem de geçirimliliğin etkisinin belirlenmesi amacıyla farklı permeabilite katsayıları dikkate alınarak analizler yapılııştır.

Zemin-su karakteristik eğrisi, filtre kağıdı yöntemi ile matrik emme ölçülerek elde edilmiştir. Araziden alınan örselenmemiş numuneler; laboratuvar ortamında $6,5 \mathrm{~cm}$ çapında ve $2,5 \mathrm{~cm}$ yüksekliğinde hazırlanarak ikişer ikişer gruplandırılmıştır. Eğrinin oluşturulabilmesi için farklı su muhtevalarında matrik emme ölçümlerinin yapılması gerekmektedir. Bu nedenle başlangıç su muhtevasına sahip numune gruplarına kontrollü olarak farklı miktarda su eklenmiştir. Bu şekilde 1slanma işlemi gerçekleştirilmiş ve örselenmemiş numunelerin farklı su içeriklerine getirilmesi sağlanmıştır. Daha sonra gruplandırılan numuneler yüzeyleri tam temas edecek şekilde üst üste getirilerek, plastik bir malzeme ile etrafları sarılıp üç gün bekletilerek su muhtevalarının dengelenmesi sağlanmıştır.

Matrik emme ölçümünde Whatman No:42 filtre kâğıdı kullanılmış ve deney ASTM-5298'e uygun olarak yapılmıştır (Şekil 2) [18]. Nem dengesi sağlandıktan sonra tüm filtre kâğıtlarının ve zemin numunelerinin su muhtevaları ölçülmüştür. Filtre kağıdı su muhtevaları için matrik emme basınçlarıASTM 5298'de Whatman No:42 filtre kağıdı için önerilen kalibrasyon eğrisi kullanılarak hesaplanmıştır. Deney sonucunda zemin numunelerinin ve filtre kâğıtlarının ölçülen su muhtevaları ve filtre kâğıdı su muhtevaları ile belirlenen matrik emmeler Tablo 2'de gösterilmektedir. 


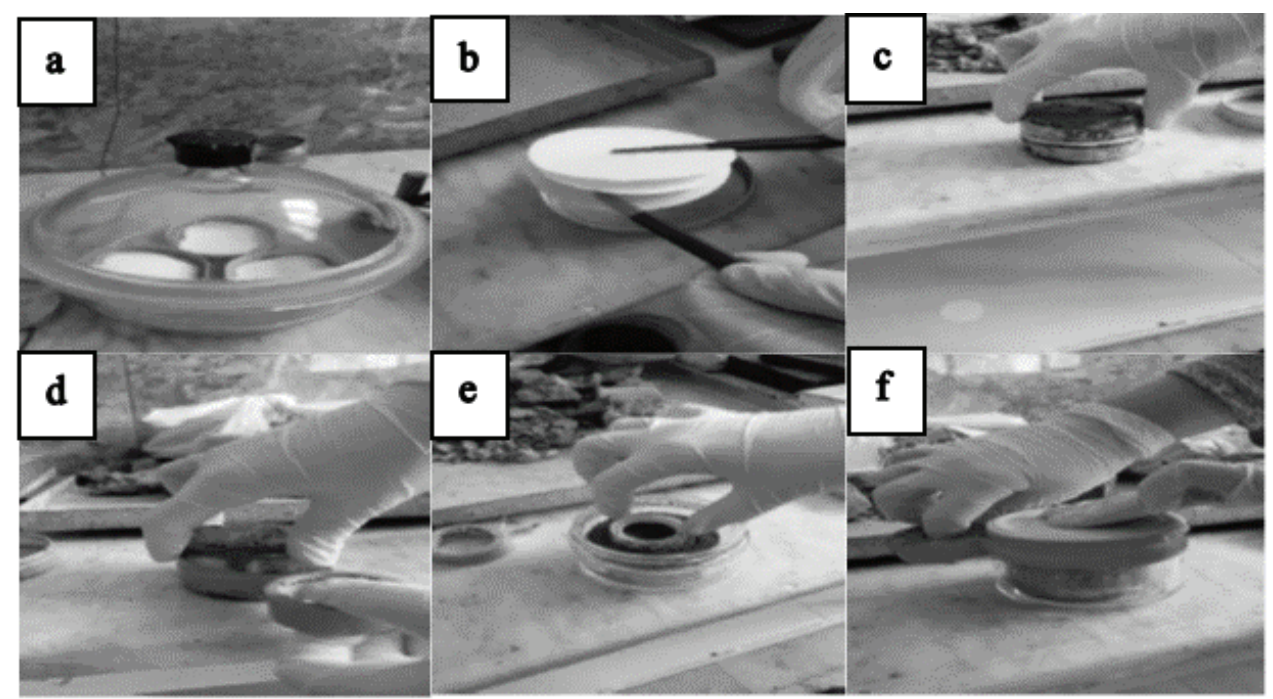

Şekil 2 - Filtre kâğıdı deneyi

a. Filtre kağıtlarının desikatör içinde bekletilmesi

b. Kullanılan filtre kağıtlarının konumlandırılması

c. Zemin tabakaları arasına filtre kağıdının yerleştirilmesi

d. Zemin numuneleri birleştirilerek etraflarının izole bantla sarılması

e. Zemin numunesinin kavanoz içine yerleştirilmesi

f. Kavanoz kapă̆ının bantlanması

Zemin-su karakteristik eğrisi, filtre kâğıdı deneyinin sonuçları kullanılarak GEOSTUDIO programının SEEP modülünde tanımlı Data-point-function seçeneği ile oluşturulmuştur (Şekil 3). Bütün zemin türlerinde, zeminin sıfır su içeriğine ulaştığı anda sahip olduğu toplam emmenin, yapılan deneysel çalışmalarla [19], [20] ve ayrıca bu çalışmaları destekleyen termodinamik prensipleriyle [6] yaklaşık $1000000 \mathrm{kPa}$ olduğu gösterilmiştir. Bu nedenle eğri oluşturulurken sıfır su içeriği için matrik emme basınc1 $1000000 \mathrm{kPa}$ olarak alınmıştır.

Ayrıca, zemin-su karakteristik eğrisi; doygun olmayan koşullardaki bir zeminin, hidrolik iletkenlik-matrik emme eğrisini elde etmekte de kullanılabilmektedir [9]. Bu çalışmada, zemin-su karakteristik eğrisinden yararlanılarak hidrolik iletkenlik-matrik emme değişiminin elde edilebilmesi için GEOSTUDIO programında tanımlı Van Genuchten (1980) fonksiyonu (6) kullanılmıştır (Şekil 4) [21].

$\Theta=\left[\frac{1}{1+\left(\frac{\psi}{a}\right)^{n}}\right]^{m}$

Denklemde; $\Theta$ normalize hacimsel su içeriği, $\psi$ zemin emmesi, a, $\mathrm{n}, \mathrm{m}$ ise şekil parametreleridir. Ayrıca zemin izotropik kabul edilerek x ve y doğrultularındaki geçirgenlik eşit olarak tanımlanmıştır. 
Doymamış Koşullardaki bir Şevin Yağış Etkisindeki Duraylılığını Etkileyen...

Tablo 2 - Filtre kâğıdı deneyi matrik emme ölçüm sonuçları

\begin{tabular}{|c|c|c|c|c|c|}
\hline Numune No & & 1 & 2 & 3 & 4 \\
\hline $\begin{array}{l}\text { Soğuk Numune Kabı } \\
\text { Ağırlığı (gr) }\end{array}$ & $\mathbf{T}_{\mathbf{c}}$ & 9.3967 & 9.2997 & 9.4233 & 9.3015 \\
\hline $\begin{array}{l}\text { Soğuk Numune Kabı+ } \\
\text { Islak Filtre Kağıdı } \\
\text { Ağırlığı (gr) }\end{array}$ & $\mathbf{M}_{1}$ & 9.7276 & 9.6669 & 9.7741 & 9.6518 \\
\hline $\begin{array}{l}\text { Sıcak numune Kabı+ } \\
\text { Kuru Filtre Kağıdı } \\
\text { Ağırlığı (gr) }\end{array}$ & $\mathbf{M}_{2}$ & 9.6441 & 9.5499 & 9.6806 & 9.5434 \\
\hline $\begin{array}{l}\text { Sicak Numune Kabı } \\
\text { Ağırlığı (gr) }\end{array}$ & $\mathbf{T}_{\mathbf{h}}$ & 9.3949 & 9.2978 & 9.4208 & 9.2981 \\
\hline $\begin{array}{l}\text { Kuru Filtre Kağıdı } \\
\text { Ağırlığı (gr) }\end{array}$ & $M_{f}=M_{2}-T_{h}$ & 0.2492 & 0.2521 & 0.2598 & 0.2453 \\
\hline Su Ağırlığı (gr) & $\begin{array}{c}\mathbf{M}_{w}=\mathbf{M}_{1}-\mathbf{M}_{2}- \\
\mathbf{T}_{\mathbf{c}}+\mathbf{T}_{\mathbf{h}}\end{array}$ & 0.0817 & 0.1151 & 0.0910 & 0.1050 \\
\hline $\begin{array}{l}\text { Filtre Kağıdı Su İçeriği } \\
(\%)\end{array}$ & $\mathbf{M}_{\mathbf{w}} / \mathbf{M}_{\mathbf{f}}$ & 0.3278 & 0.4565 & 0.3503 & 0.4280 \\
\hline Matrik Emme (kPa) & & 593.52 & 59.00 & 400.68 & 89.45 \\
\hline $\begin{array}{l}\text { Zemin Su Muhtevası } \\
(\%)\end{array}$ & & 0.21 & 0.34 & 0.23 & 0.33 \\
\hline
\end{tabular}

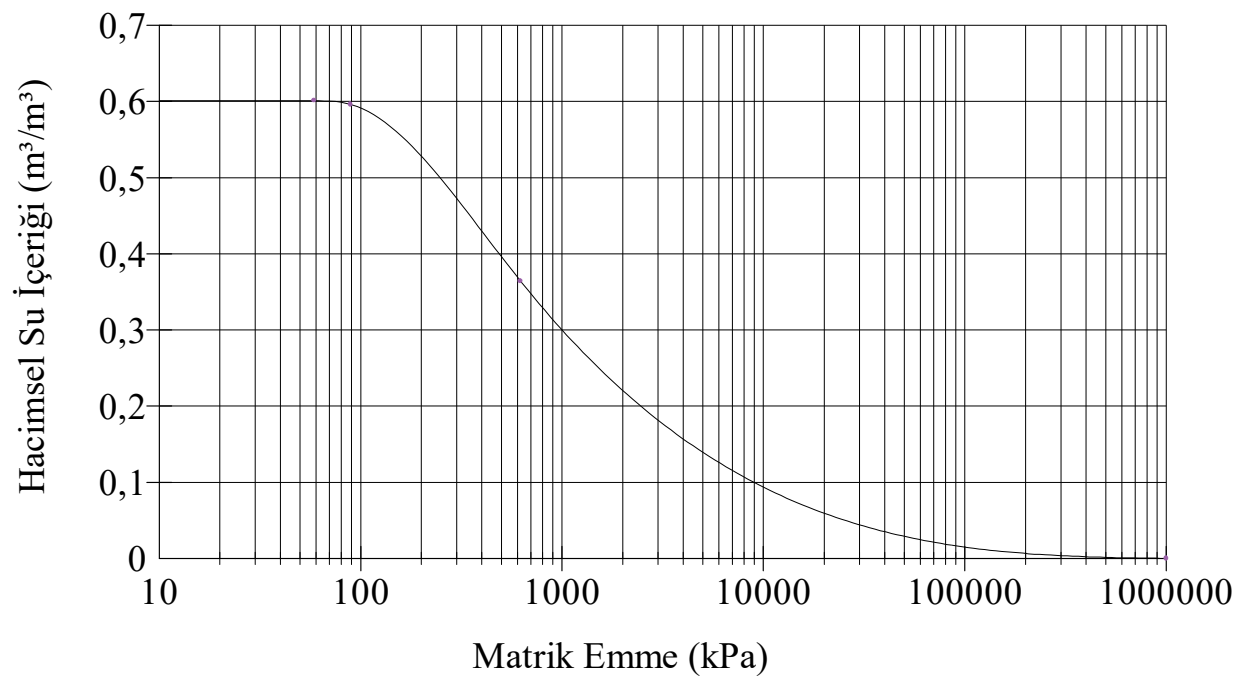

Şekil 3 - Zemin-su karakteristik ĕgrisi

Şev analizleri için gerekli olan doygun olmayan koşullardaki kayma mukavemeti parametreleri konsolidasyonlu-drenajsız üç eksenli basınç deneyinden (CU) elde edilen 
efektif içsel sürtünme açısı $\phi^{\prime}$ ve efektif kohezyon, $c^{\prime}$, ayrıca kayma mukavemeti parametresi $\phi^{b}$ 'den yararlanılarak elde edilebilmektedir.

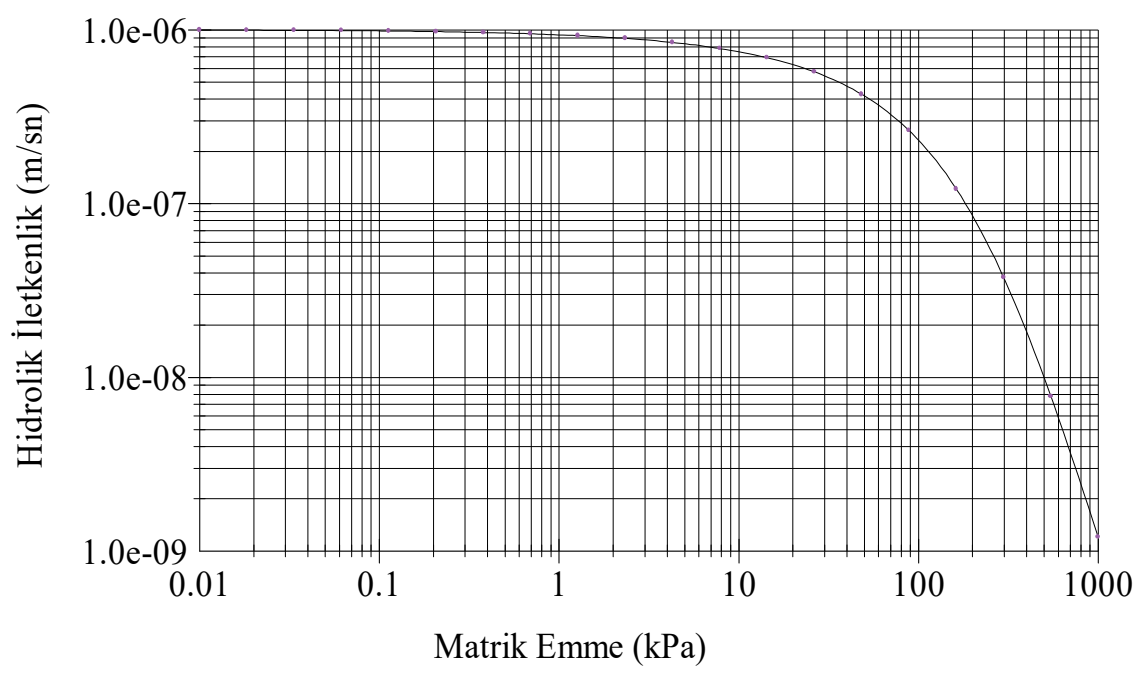

Şekil 4 - Hidrolik iletkenlik ĕgrisi

Kayma mukavemeti parametresi $\phi^{\mathrm{b}}$ ise zemin su karakteristik eğrisinden elde edilen rezidüel $\left(\Theta_{\mathrm{r}}\right)$, doygun $\left(\Theta_{\mathrm{s}}\right)$ ve doğal $(\Theta)$ hacimsel su içerikleri kullanılarak (7) ile hesaplanmıştır (Tablo 3).

$\tan \phi^{b}=\left[\left(\tan \phi^{\prime}\right)\left(\frac{\theta-\theta_{r}}{\theta_{s}-\theta_{r}}\right)\right]$

Yapılan çalışmalar zeminin efektif içsel sürtünme açısının matrik emme değişiminden minimal düzeyde etkilendiğini ortaya koymaktadır [22], [23], [24]. Dolayısı ile doygun olmayan koşullarda zemin kayma mukavemetindeki değişim, matrik emmeye bağlı olarak kohezyonda meydana gelen değişimden kaynaklanmaktadır (8).

$\mathrm{c}=\mathrm{c}^{\prime}+\left(\mathrm{u}_{\mathrm{a}}-\mathrm{u}_{\mathrm{w}}\right) \tan \phi^{\mathrm{b}}$

Tablo 3 - Zemine ait hacimsel su içerikleri ve kayma mukavemeti parametreleri

\begin{tabular}{|c|c|c|c|c|c|}
\hline $\begin{array}{c}\text { Rezidüiel } \\
\text { hacimsel su } \\
\text { içeriği, } \theta \mathbf{r} \\
(\%)\end{array}$ & $\begin{array}{c}\text { Doygun } \\
\text { hacimsel su } \\
\text { içeriği, } \theta \text { s } \\
(\%)\end{array}$ & $\begin{array}{c}\text { Doğal } \\
\text { hacimsel } \\
\text { su içeriği, } \\
\theta \\
(\%)\end{array}$ & $\begin{array}{c}\text { Matrik emmeye bağlı } \\
\text { kayma mukavemeti } \\
\text { artış miktarını } \\
\text { gösteren açı, } \phi^{\mathrm{b}} \\
\left({ }^{\circ}\right)\end{array}$ & $\begin{array}{c}\text { Efektif } \\
\text { kohezyon,c' } \\
(\mathbf{k P a})\end{array}$ & $\begin{array}{l}\text { Efektif içsel } \\
\text { sürtünme } \\
\text { açısı, } \phi ’ \\
\left({ }^{\circ}\right)\end{array}$ \\
\hline 0.07 & 0.6 & 0.39 & 8.82 & 15 & 14 \\
\hline
\end{tabular}




\section{DOYGUN OLMAYAN KOŞULLARDAKİ ŞEVİN YAĞIŞ ETKİSİNDEKİ DURAYLILIĞINI ETKILEYEN PARAMETRELERIN İNCELENMESİ}

Mevcut çalışmada, doygun olmayan koşullardaki bir zeminde yağış yoğunluğunun, süresinin, zeminin doygun geçirgenliğinin ve şev eğiminin duraylılığa olan etkisi, sahadan elde edilen zeminin özellikleri ve yağış verileri genişletilerek; yarı parametrik yöntemle incelenmiştir.

Yağış yoğunlukları, Meteoroloji Genel Müdürlüğü’nden Baykan İlçesi için alınan dört yıla ait saatlik yağış verileri düzenlenerek hesaplanmıştır. Yağış verileri incelendiğinde bölgede dört yıl içerisinde yıllık ortalama $821 \mathrm{~mm}$ yağış meydana geldiği ve yıllık yağışın yaklaşık \%60’ının Ocak, Şubat ve Mart aylarında gerçekleştiği görülmektedir (Şekil 5).

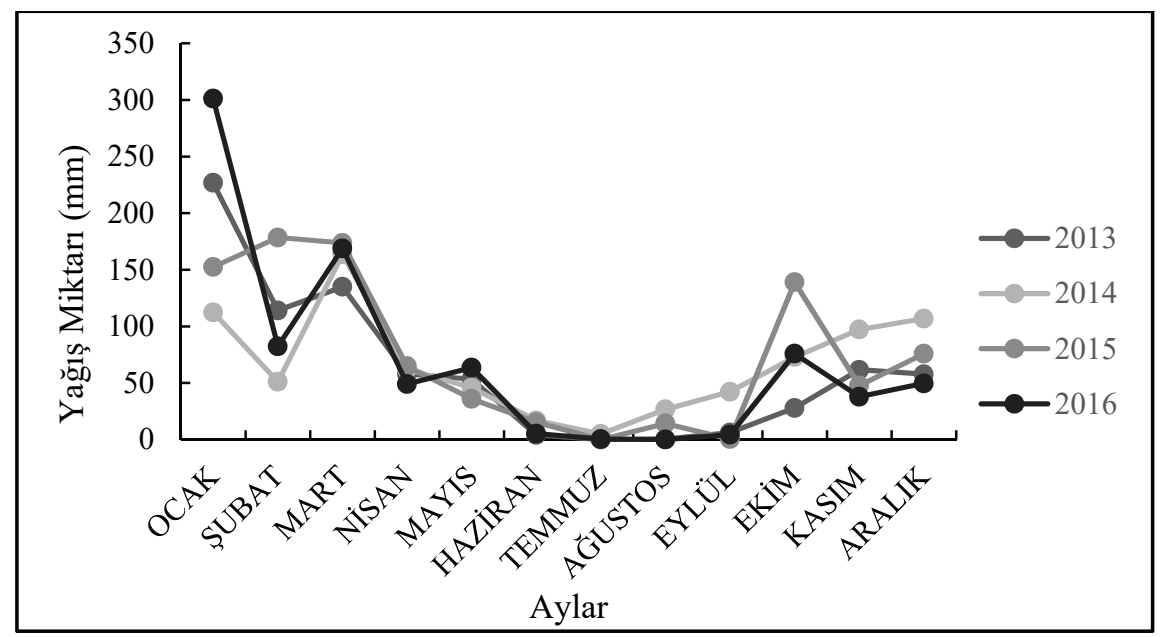

Şekil 5 - Yıllara göre aylık toplam yă̆ış miktarları

Sızma ve şev analizleri doygun olmayan zemin özelliklerinin tanımlanabildiği malzeme modellerini içeren ve bu nedenle araştırmalarda yaygın olarak tercih edilen GEOSTUDIO programı kullanılarak gerçekleştirilmiştir. SEEP modülü doygun ve doygun olmayan zeminlerde meydana gelen su akımlarını nümerik olarak modellemeyi sağlar. SLOPE modülü karmaşık şev problemlerinin, klasik limit-denge yöntemleriyle çözülmesinde büyük kolaylık sağlamaktadır.

Doygun olmayan zeminlerin duraylılığı incelenirken, en önemli parametrelerden biri zeminin başlangıç boşluk suyu basıncı (matrik emme) dağılımıdır ve bu; yeraltı suyu seviyesi, yağış yoğunluğu, yıllık yağış/buharlaşma oranı vb. birçok faktörden etkilenmektedir. Başlangıç koşullarının oluşturulması amacıyla, SEEP modülünde, yeraltı su seviyesi model sınırlarına hidrolik yük sınır koşulu ile tanımlanmıştır.Uzun dönem koşulların modellenebilmesi amacıyla kararlı durum (steady-state) analizi yapılarak başlangıç boşluk suyu basıncı dağılımı (emme basıncı) elde edilmiştir. Boşluk suyu basıncı dağılımı esas alınarak yapılan 
duraylılık analizinde, doygun olmayan zeminin yağış öncesi $(\mathrm{t}=0)$ sahip olduğu güvenlik sayıs1 1.801 olarak bulunmuştur (Şekil 6).

Yağışın doygun olmayan koşullardaki zeminlere olan etkisi genel olarak, yeraltı su seviyesindeki değişim, yüzeyde doygun bölge oluşumu ve doygunluk sınırının ilerlemesi ve ayrıca vadoz bölgede negatif boşluk suyu basıncının değişimiyle (azalması) gözlenebilir. Burada, sızmanın düzeyi; hidrolik iletkenliğe, başlangıç gerilme koşullarına, zeminin hacimsel su içeriğine, matrik emmedeki değişimin hızına, yağış yoğunluğuna ve süresine vb. çoklu değişkene bağlı oldukça karmaşık bir fenomendir. Mevcut çalışmada, bu faktörler SEEP modülünde oluşturulan modelde tanımlanarak yağış sonucunda oluşan sızma nedeniyle zeminin boşluk suyu basıncı dağılımında meydana gelen değişim kararsız akım koşulunda (transient seepage) elde edilmiştir.

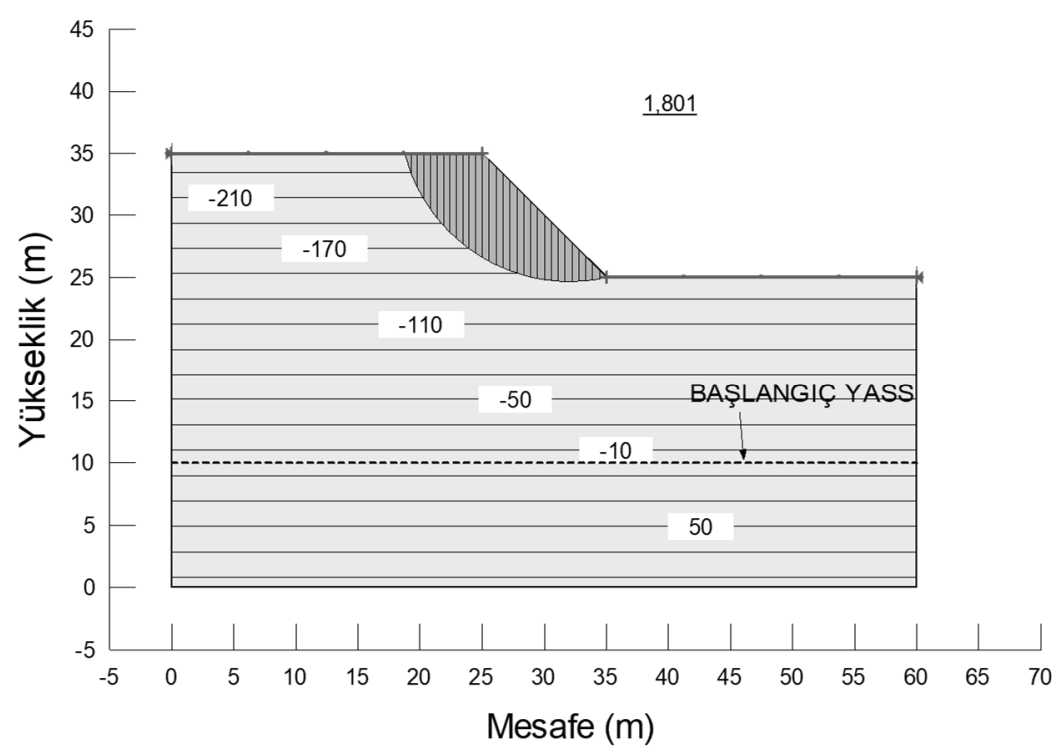

Şekil 6 - Başlangıç koşulunda boşluksuyu basıncı dağılımı ve şev güvenlik sayısı

\subsection{Yağıș Yoğunluğunun Şev Duraylılığına Etkisi}

Yağış yoğunluğu etkisini araştırmak amacıyla gerçekleştirilen şev analizleri, incelenen bölgede yağışın en yoğun miktarda meydana geldiği aylar için yapılmıştır. Üç ay süreli analizlerde her yıla ait Ocak-Şubat-Mart aylarının toplam yağış miktarları; yüzey akışı ve buharlaşma dikkate alınıp, \%30 oranında azaltılarak kullanılmış ve değişimin etkisini görebilmek amacı ile bu yağış miktarlarından daha düşük ve daha yüksek iki farklı yağış miktarı için de analizler yapılmıştır. Bu şekilde hem gerçek yağış verileri ile şevin mevcut davranışının anlaşılması, hem de farklı yağış yoğunlukları kullanılarak, yağış yoğunluğunun etkisi yarı-parametrik olarak araştırılmıştır. Tablo 4'te farklı yağış yoğunlukları için yapılan analizlerde kullanılan yağış yoğunlukları ve yağış süreleri görülmektedir. Sızma analizleri 
için tanımlı süre ve yağış yoğunlukları dikkate alınarak kararsız akım koşulunda (transient seepage) analizler gerçekleştirilmiş ve boşluk suyu basıncı dağılımı elde edilmiştir.

Tablo 4 - Yă̆̆ş yoğunluğu etkisinin incelendiği analizlerde kullanılan yağış parametreleri

\begin{tabular}{cccc}
\hline Yıllar & $\begin{array}{c}\text { Toplam yağıș m ktarı } \\
(\% 30 \text { azaltılmış) } \\
(\mathbf{m m})\end{array}$ & $\begin{array}{c}\text { Toplam süre } \\
\text { (ay) }\end{array}$ & $\begin{array}{c}\text { Yağış yoğunluğu } \\
(\mathbf{m} / \mathbf{s n})\end{array}$ \\
\hline- & 200 & 3 & $2.57 \times 10^{-8}$ \\
2013 & 333 & 3 & $4.28 \times 10^{-8}$ \\
2014 & 229 & 3 & $2.95 \times 10^{-8}$ \\
2015 & 353 & 3 & $4.54 \times 10^{-8}$ \\
2016 & 387 & 3 & $4.97 \times 10^{-8}$ \\
- & 400 & 3 & $5.14 \times 10^{-8}$ \\
\hline
\end{tabular}

Yağış sonrasındaki yeraltı suyu seviyesi ve boşluk suyu basınçları dikkate alınarak ve SLOPE modülünde tanımlı Modifiye Mohr-Coulomb malzeme modeli kullanılarak, doygun olmayan kayma mukavemeti parametreleri ile şev duraylılık analizleri yapılmıştır (Şekil 7). Bu sayede yağış nedeniyle boşluk suyu basıncında meydana gelen artışın, kayma dayanımına etkisi dikkate alınmıştır. Yağış sonrasında şev güvenlik sayısının, yağış yoğunluğu artışına bağlı olarak düştüğü gözlemlenmiştir.

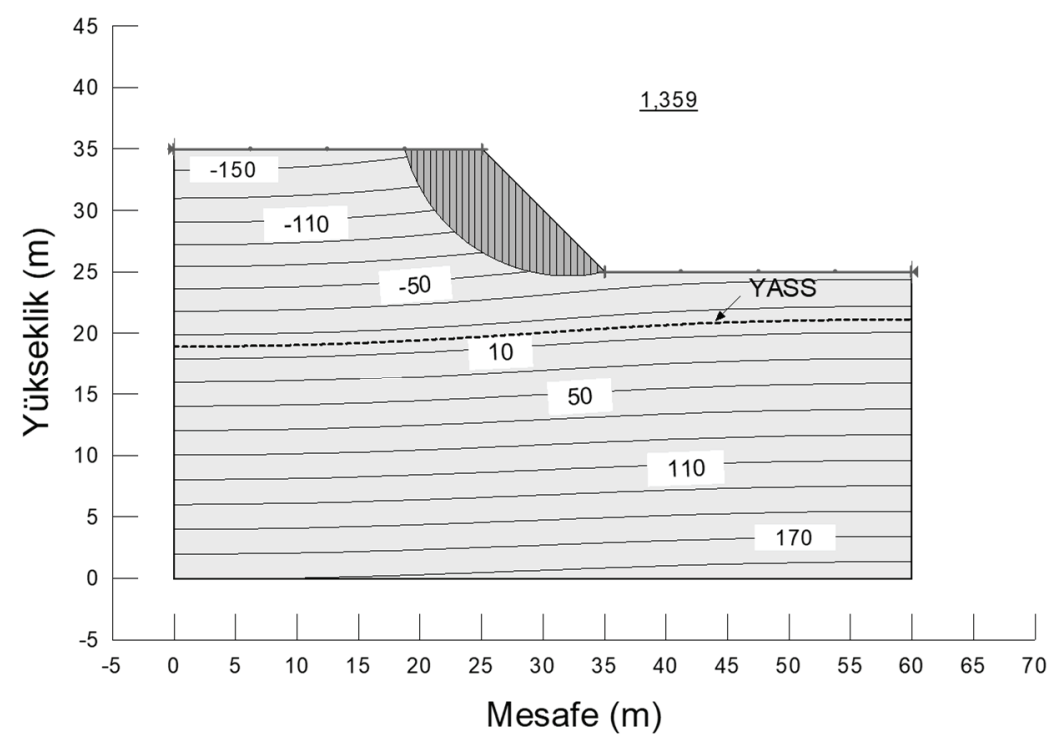

Şekil 7 - 353 mm yă̆ış sonrasında boşluk suyu basıncı dağılımı ve şev güvenlik sayısı 
Yapılan analizlerde, yağış yoğunluğu ile güvenlik sayısı arasında doğrusal olmayan bir ilişki olduğu görülmektedir (Şekil 8). Bu durumun zemine su girdisi düzeyinin büyüklüğü ile ilgili olduğu düşünülmektedir. Yağış yoğunluğu (ve dolayısıyla zemine sızan su) ile geçirgenlik arasında döngüsel bir ilişki bulunmaktadır. Yağış yoğunluğu arttıkça zemin hidrolik iletkenliği de doğrusal olmayan şekilde artarken, zemine daha fazla su sızmasına neden olmakta ve sonuçta hacimsel su içeriği artarken matrik emme de benzer şekilde azalmaktadır. Matrik emmede meydana gelen bu azalmaya bağlı olarak zeminin kayma mukavemeti de azalmakta ve bu durum yağış yoğunluğu ile güvenlik sayıları arasındaki doğrusal olmayan ilişkiyi meydana getirmektedir.

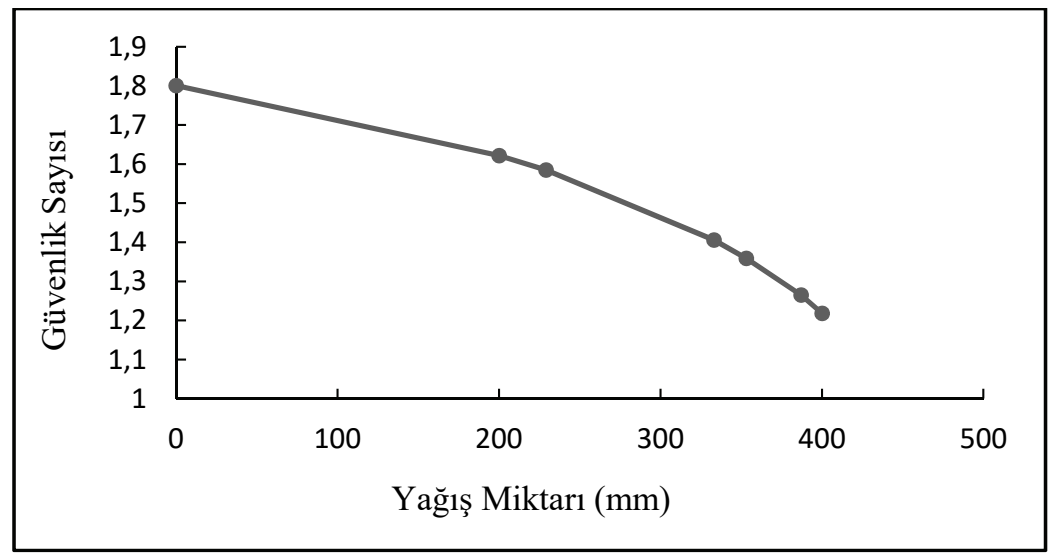

Şekil 8 - Yă̆ış miktarı ile güvenlik sayısı arasındaki ilişki

\subsection{Yağış Süresinin Şev Duraylılığına Etkisi}

Yağış süresinin şev duraylılığına etkisinin belirlenmesi için yağış verilerinden günlük, aylık ve üç aylık maksimum yağış miktarları \%30 oranında azaltılarak analizlerde kullanılmıştır (Tablo 5). Sızma için tanımlı süre ve yağış yoğunlukları dikkate alınarak kararsız akım koşulunda (transient seepage) analizler gerçekleştirilmiş ve boşluksuyu basıncı dağılımı elde edilmiştir.

Tablo 5 - Yă̆ış süresi etkisinin incelendiği analizlerde kullanılan yă̆ış parametreleri

\begin{tabular}{|c|c|c|c|}
\hline Yağış Türüi & $\begin{array}{c}\text { Toplam Yağış } \\
\text { Miktarı } \\
\text { (\%30 azaltılmış) } \\
\text { (mm) }\end{array}$ & $\begin{array}{l}\text { Yağış Yoğunluğu } \\
\text { (mm/gün) }\end{array}$ & $\begin{array}{l}\text { Analiz-Yağış } \\
\text { Süresi } \\
\text { (gün) }\end{array}$ \\
\hline $\begin{array}{l}3 \text { aylık toplam } \\
\text { maksimum yağış }\end{array}$ & 387 & 4,3 & 90 \\
\hline $\begin{array}{l}\text { Aylik toplam } \\
\text { maksimum yağış }\end{array}$ & 211 & 7,03 & 30 \\
\hline $\begin{array}{l}\text { Günlük toplam } \\
\text { maksimum yağış }\end{array}$ & 48 & 48 & 3 \\
\hline
\end{tabular}


Günlük, aylık ve üç aylık yağışların sonundaki boşluk suyu basını dağılımları ile güvenlik sayıları sırasıyla Şekil 9-10-11'de görülmektedir. Analiz sonuçlarına göre şevin başlangıç koşulunda güvenlik sayısı 1.801 iken; üç günlük yoğun yağış sonunda 1.674 'e, aylık yağış sonunda 1.665 'e ve üç aylık yağış sonrasında 1.265 'e düşmüştür (Şekil 12).

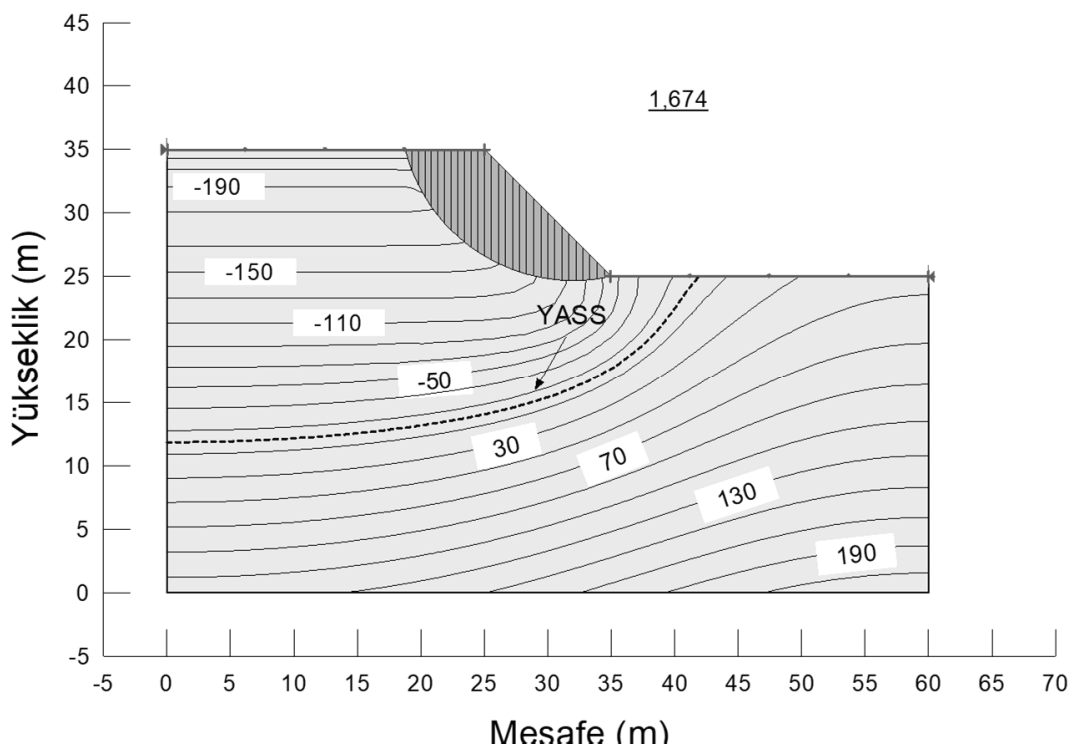

Şekil 9 - Ü̧̧ günlük yă̆ış sonunda boşluksuyu basıncı dăğlımı ve güvenlik sayısı

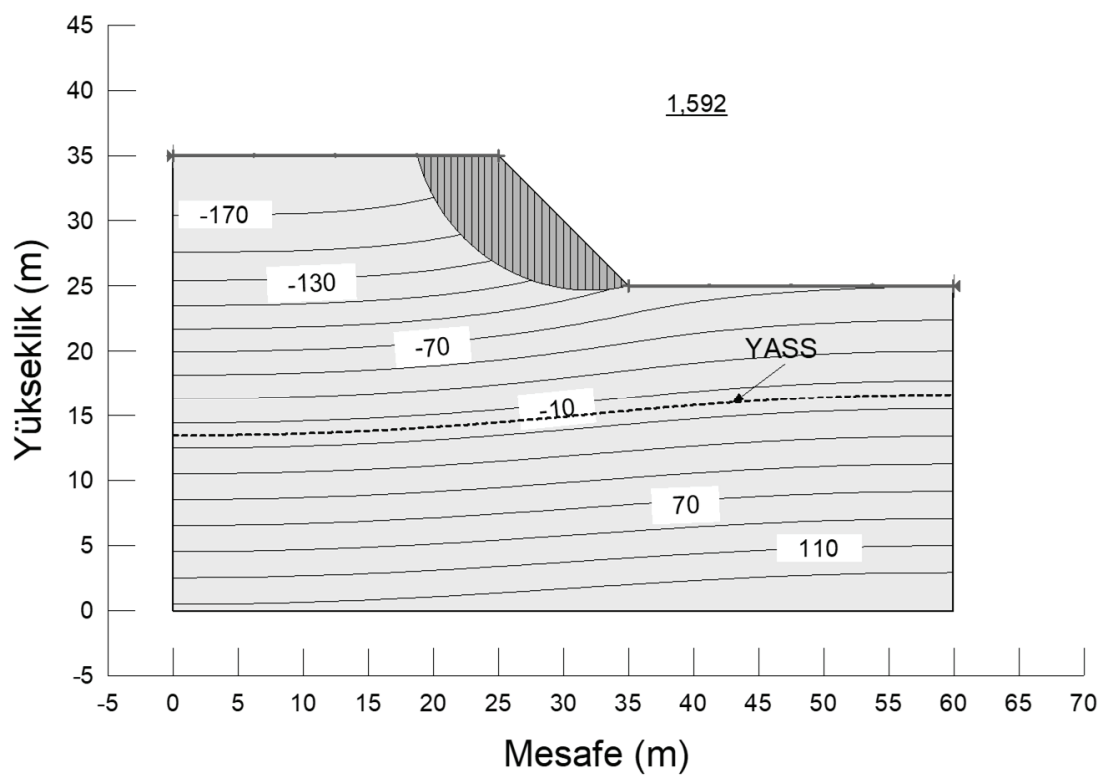

Şekil 10 - Bir aylık yă̆ış sonunda boşluksuyu basıncı dağılımı ve güvenlik sayısı 


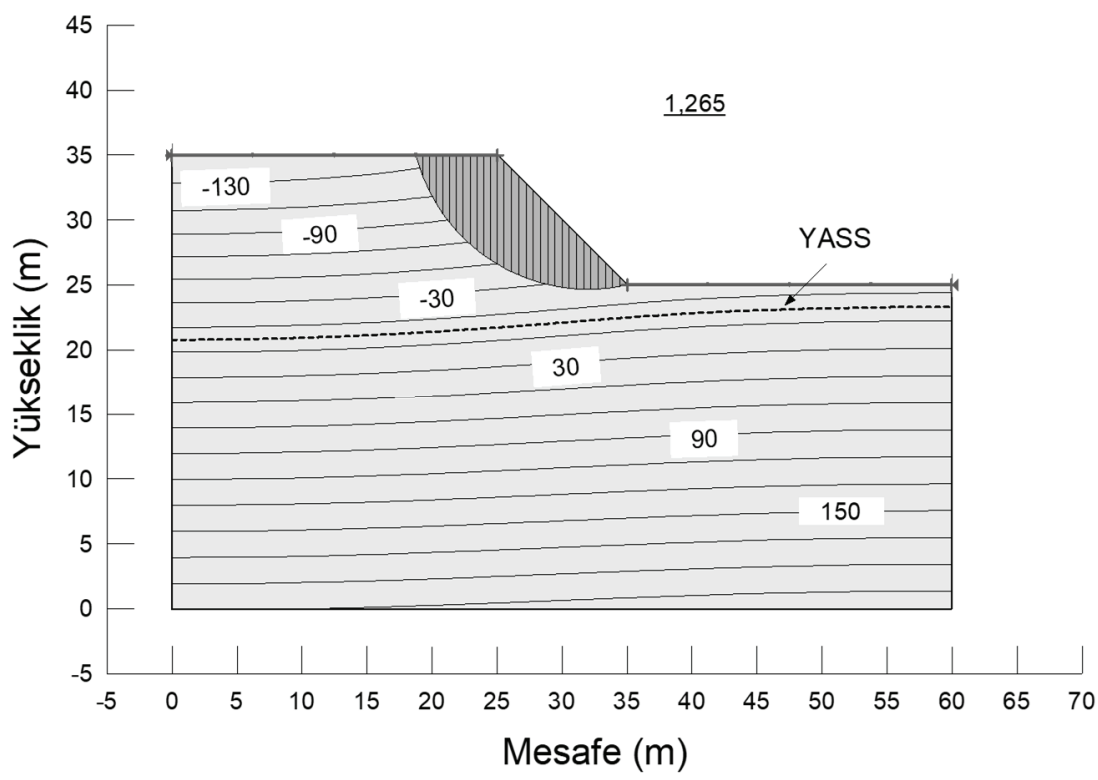

Şekil 11 - Ü̧̧ aylık yağı̧s sonunda boşluksuyu basıncı dağıllımı ve güvenlik sayısı

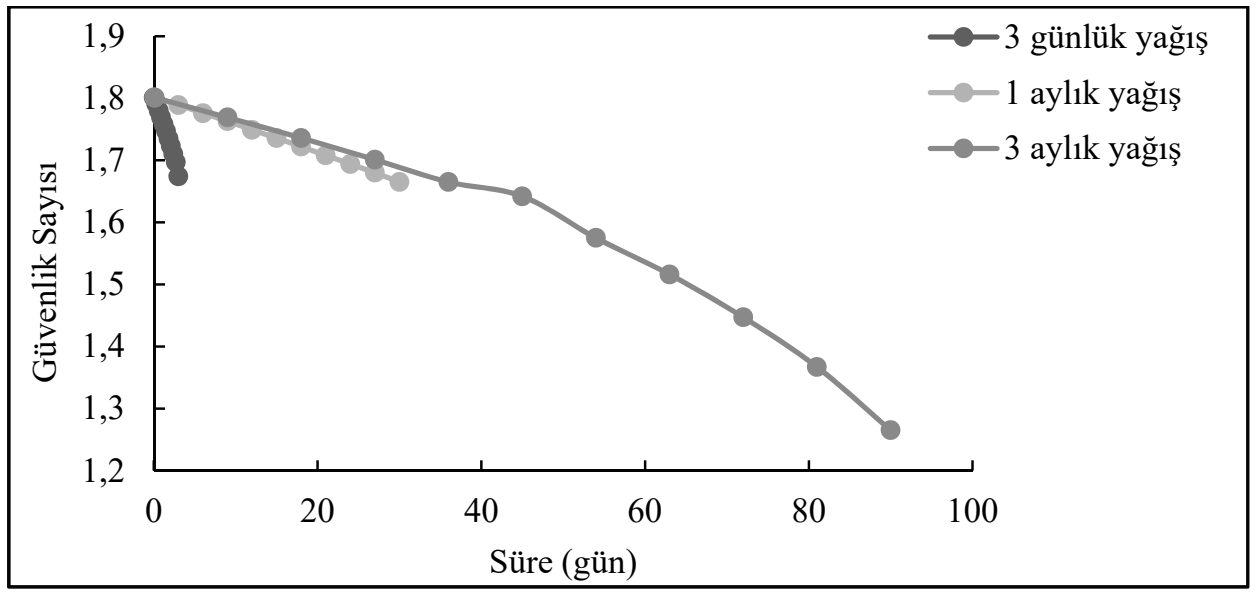

Şekil 12 - Yă̆ğs süresine bağll olarak güvenlik sayısında meydana gelen değişim

Yapılan analizlerde; kısa süreli görece yoğun yağışta şev topuğuna yakın bölgede yeraltı su seviyesi topuk bölgesine doğru kabarmış ve bunun sonucunda muhtemel kayma yüzeylerini içine alan / yakınında yer alan bölgede matrik emme dikkate değer oranda azalmıştır. Şev topuk bölgesinde meydana gelen bu kabarmanın, yoğun yağış altında zemine sızan su miktarının nispeten fazla olmasına karşın, kısa süreli gerçekleşen drenajın düşük miktarda olması ve buna bağlı olarak boşluk suyu basıncının dikkate değer mertebede değişmesinden 
kaynaklandığı düşünülmektedir.. Matrik emmede gerçekleşen azalma, zemin mukavemetini kaybetmesine ve sonuçta güvenlik sayısında azalmaya neden olmaktadır. Bu sebeple yoğun fakat kısa süreli olan üç günlük yağış sonucunda güvenlik sayısında meydana gelen değişimin, bir ay süreli yağışın meydana getirdiği değişime çok olduğu görülmektedir. Bu durum kısa süreli fakat yoğun yağışların stabilite üzerinde ne kadar etkili olduğunu ve bu koşullarda şev göçmelerinin neden sıklıkla gözlemlendiğini de açıklamaktadır.

\subsection{Zemin Geçirgenliğinin Şev Duraylılığına Etkisi}

Çalışmanın bu kısmında, zemin geçirgenliğinin sızmaya ve buna bağlı olarak şev duraylılığına olan etkileri araştırılmıştır. Analizlerde kullanılan farklı permeabilite katsayıları ve dört yıla ait maksimum üç aylık yağış verisi Tablo 6'da görülmektedir.

Tablo 6 - Zemin geçirgenliği etkisinin incelendiği analizlerde kullanılan yağış parametreleri

\begin{tabular}{cccc}
\hline $\begin{array}{c}\text { Zemin Geçirimliliği } \\
(\mathbf{m} / \mathbf{s n})\end{array}$ & $\begin{array}{c}\text { Toplam Yağış } \\
\text { Miktarı (mm) }\end{array}$ & $\begin{array}{c}\text { Yağış Yoğunluğu } \\
(\mathbf{m} / \mathbf{s n})\end{array}$ & $\begin{array}{c}\text { Analiz-Yağış } \\
\text { Süresi (gün) }\end{array}$ \\
\hline $5 \times 10^{-7}$ & 387 & $4.97 \times 10^{-8}$ & 90 \\
$10^{-6}$ & 387 & $4.97 \times 10^{-8}$ & 90 \\
$5 \times 10^{-5}$ & 387 & $4.97 \times 10^{-8}$ & 90 \\
\hline
\end{tabular}

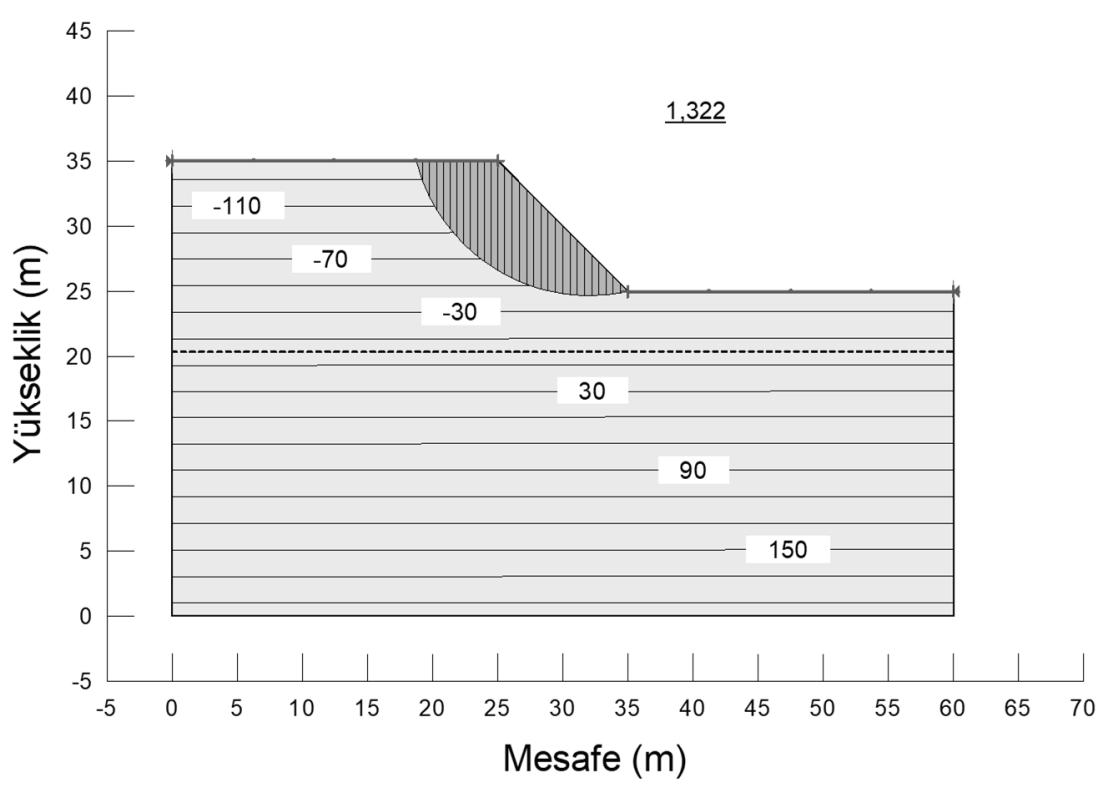

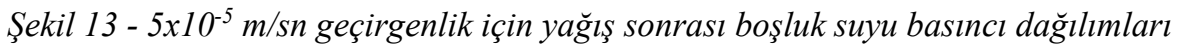


Yağış sonrası boşluk suyu basıncı dağılımlarından (Şekil 13-14-15) görüldüğü üzere, yeraltı su seviyesinde, şevin topuk bölgesine doğru bir kabarma meydana gelmiş ve zeminin permeabilitesi azaldıkça, topuk bölgesinde yeraltı su seviyesindeki kabarma düzeyi artarak, güvenlik sayısında daha fazla azalma meydana gelmiştir (Şekil 16).

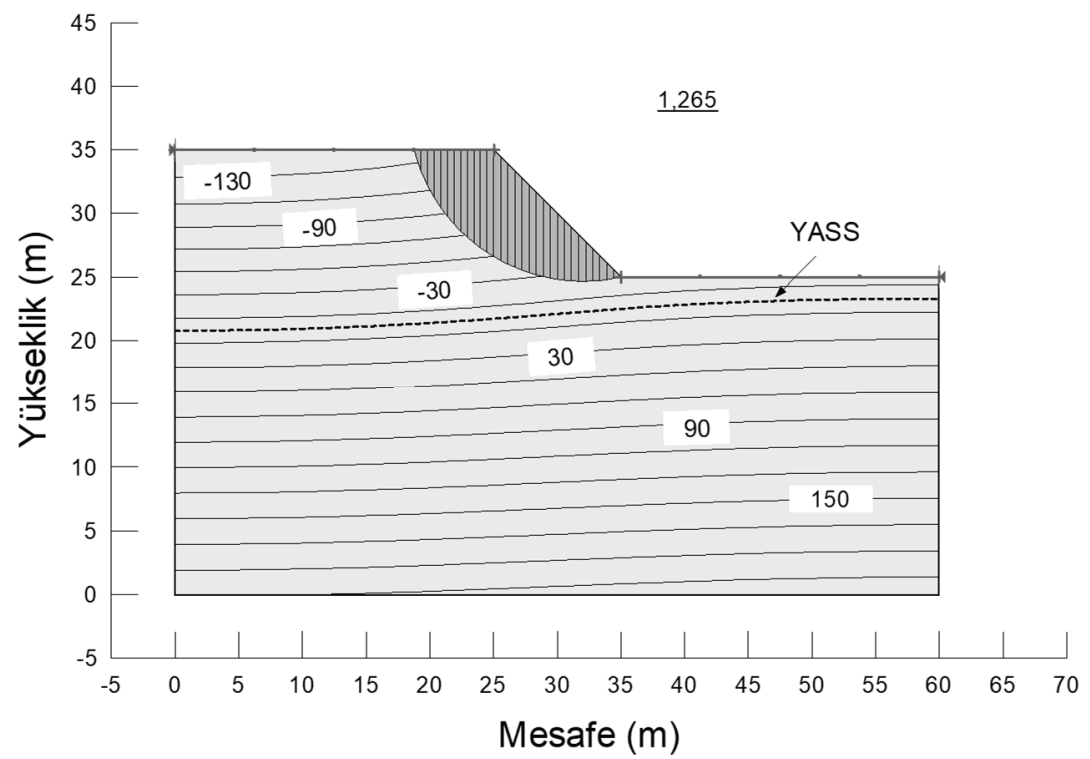

Şekil $14-10^{-6} \mathrm{~m} / \mathrm{sn}$ geçirgenlik için yă̆ış sonrası güvenlik sayısı

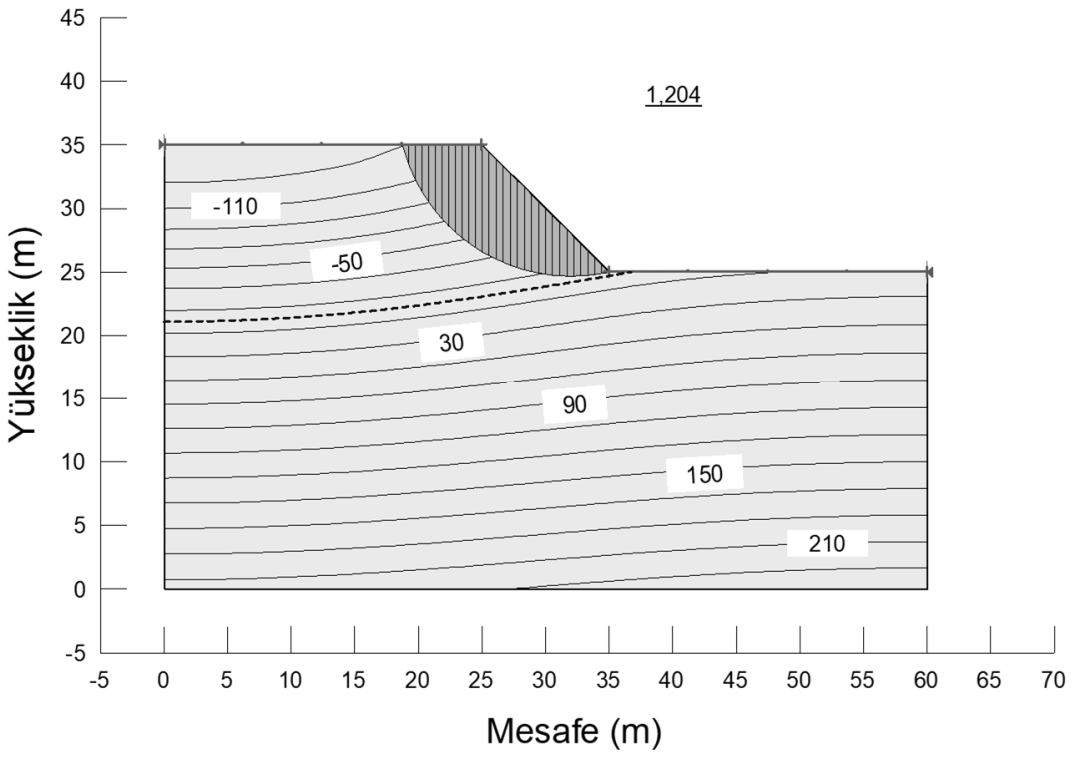

Şekil $15-5 \times 10^{-7} \mathrm{~m} / \mathrm{sn}$ geçirgenlik için yă̆ış sonrası güvenlik sayısı 


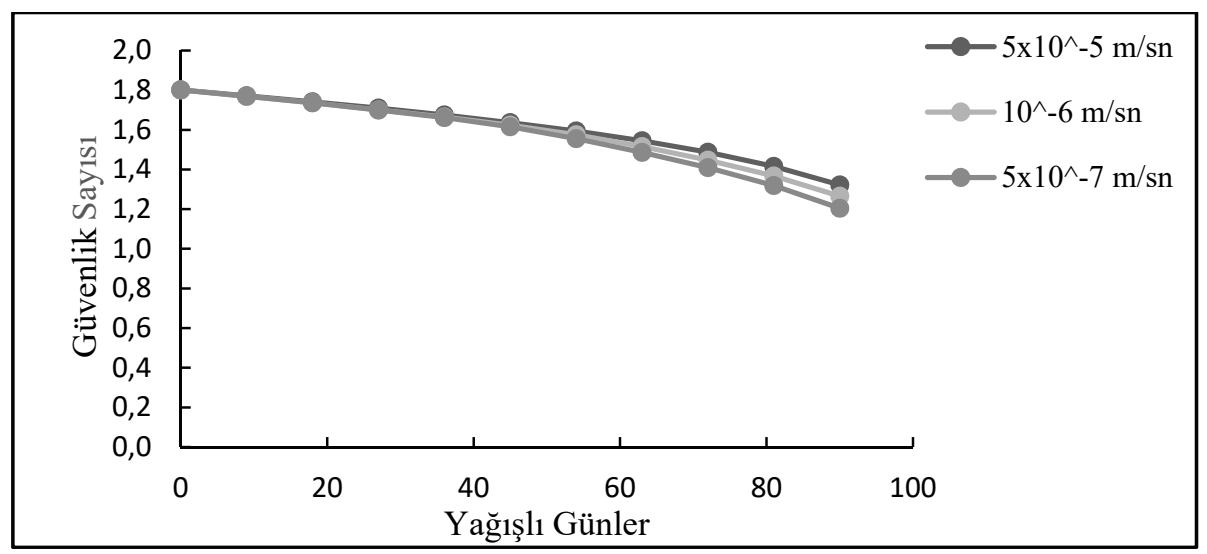

Şekil 16 - Zemin geçirgenliğine bağll güvenlik sayllarının zamana bağlı değişimi

Şekil 16'dan görülebileceği üzere, zeminin permeabilitesi azaldıkça güvenlik sayısında da azalma meydana gelmiştir. Bu durumun sızma-drenaj dengesinin, boşluk suyu basıncı üzerindeki etkisiyle açıklanabileceği düşünülmektedir. Geçirgenliği göreli yüksek zeminlerde zemine daha fazla su sizarken, eş zamanlı olarak daha fazla su drene olabilmekte ve bundan dolayı boşluk suyu basıncında değişim minimal düzeyde kalmaktadır. Bu durum şev güvenlik sayısının sızmadan fazla etkilenmemesine sebep olmaktadır. Öte yandan geçirgenliği çok düşük olan zeminlerde sızma düşük miktarda gerçekleştiği için boşluk suyu basıncındaki değişim fazla olmamakta ve yine benzer şsekilde şev yağıștan göreli olarak daha az etkilenmektedir. Ara geçirgenliğe sahip zeminlerde (ör: $10^{-4} \mathrm{~m} / \mathrm{sn}-10^{-7} \mathrm{~m} / \mathrm{sn}$ ) yağış parametrelerine bağlı olarak, sızma-drenaj dengesi boşluksuyu basıncı değişimi üzerinde etkili olmakta ve bu durum güvenlik sayısını dikkate değer mertebede düşürmektedir. Elde edilen bu bulgular literatür ile de benzerlik göstermektedir [1]. Boşluksuyu basıncındaki değişim (matrik emme değişimi) ise zemin mukavemetinde azalmaya ve buna bağlı olarak güvenlik sayısında düşüşe neden olmaktadır. Bu çalışmada saha ölçümleri ile elde edilen geçirgenlik katsayılarının yukarıda geçen "ara geçirgenlik" düzeyinde olduğu söylenebilir. Geçirgenliklerin bu aralıkta olması, zeminin boşluksuyu basınçlarının yağıştan daha fazla etkilenmesine ve güvenlik sayısının daha geniş bir aralıkta değişmesine ve mevcut zeminde yağış sonrası görülen şev duraysızlıklarına da açıklık getirmektedir.

\section{4. Şev Eğiminin Duraylılığa Etkisi}

Yağışa maruz doygun olmayan koşullardaki şev eğiminin, yağış sonrasındaki güvenlik sayısında meydana gelen azalmaya olan etkisi incelenmiştir. $\mathrm{Bu}$ amaçla, analizlerde kullanılan $45^{\circ}$ eğime ek olarak $30^{\circ}$ ve $60^{\circ}$ eğimler için de farklı yağış yoğunlukları dikkate alınarak şev analizleri yapılmıştır. Analizlerde kullanılan şev eğimleri ve yağış yoğunlukları Tablo 7'de görülmektedir.

Başlangıç koşulları dikkate alınarak yapılan şev analizlerinde, eğime bağlı olarak güvenlik sayıları; $30^{\circ}$ için $2.109,45^{\circ}$ eğim için 1.801 ve $60^{\circ}$ eğim için 1.560 olarak elde edilmiştir. 
Yağış sonrası boşluk suyu basınçları ve şev güvenlik sayıları Şekil 17-18-19'da görülmektedir.

Tablo 7 - Şev eğimi etkisinin incelendiği analizlerdeki yă̆ış parametreleri

\begin{tabular}{cccc}
\hline $\begin{array}{c}\text { Şev Eğimi } \\
\left({ }^{\circ}\right)\end{array}$ & $\begin{array}{c}\text { Toplam Yağış } \\
\text { Miktarı }(\mathbf{m m})\end{array}$ & $\begin{array}{c}\text { Yağış Yoğunluğu } \\
(\mathbf{m} / \mathbf{s n})\end{array}$ & $\begin{array}{c}\text { Analiz-Yağış } \\
\text { Süresi (gün) }\end{array}$ \\
\hline \multirow{3}{*}{$30^{\circ}$} & 200 & $2.57 \times 10^{-8}$ & \\
& 333 & $4.28 \times 10^{-8}$ & \\
& 229 & $2.95 \times 10^{-8}$ & \\
353 & $4.54 \times 10^{-8}$ & \\
& 387 & $4.97 \times 10^{-8}$ & \\
$45^{\circ}$ & 200 & $2.57 \times 10^{-8}$ & \\
& 333 & $4.28 \times 10^{-8}$ & \\
& 229 & $2.95 \times 10^{-8}$ & \\
& 353 & $4.54 \times 10^{-8}$ & \\
& 387 & $4.97 \times 10^{-8}$ & \\
& 200 & $2.57 \times 10^{-8}$ & \\
& 333 & $4.28 \times 10^{-8}$ & \\
& 229 & $2.95 \times 10^{-8}$ & \\
& 353 & $4.54 \times 10^{-8}$ & \\
& 387 & $4.97 \times 10^{-8}$ & \\
\hline
\end{tabular}

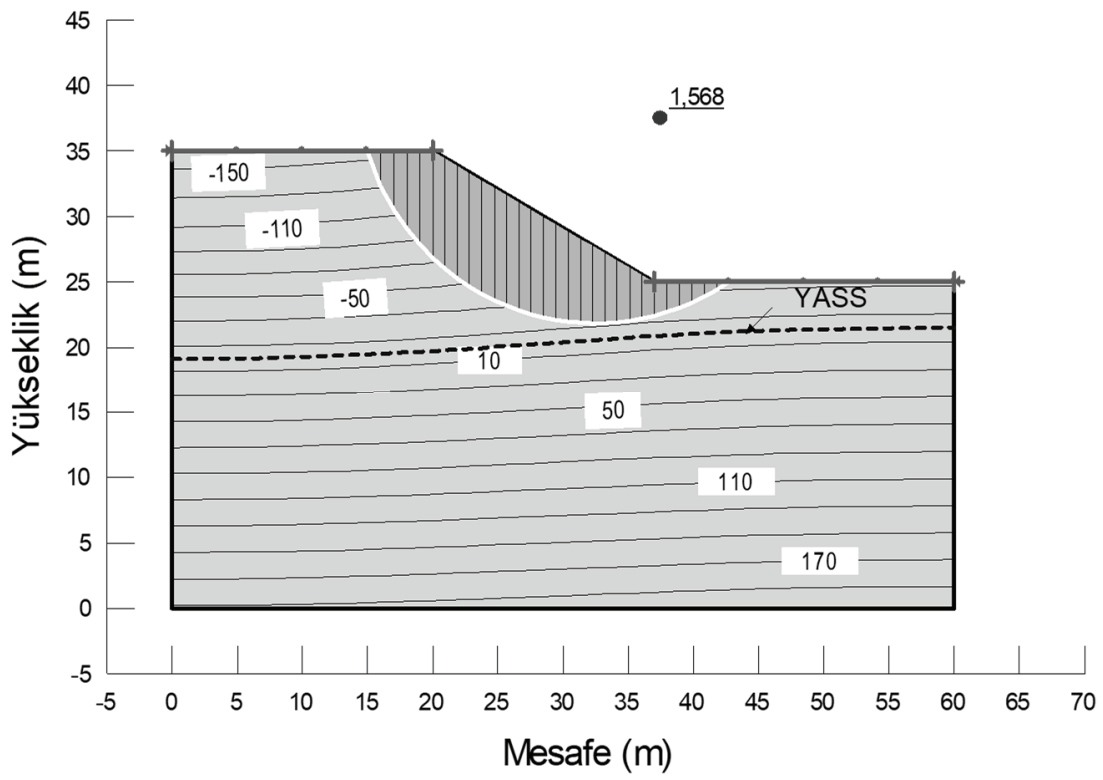

Şekil 17 - 30 eğimli şevin 353 mm yă̆ış sonrasında boşluk suyu basıncı dağılımı ve güvenlik sayıs 
Doymamış Koşullardaki bir Şevin Yağış Etkisindeki Duraylllığını Etkileyen...

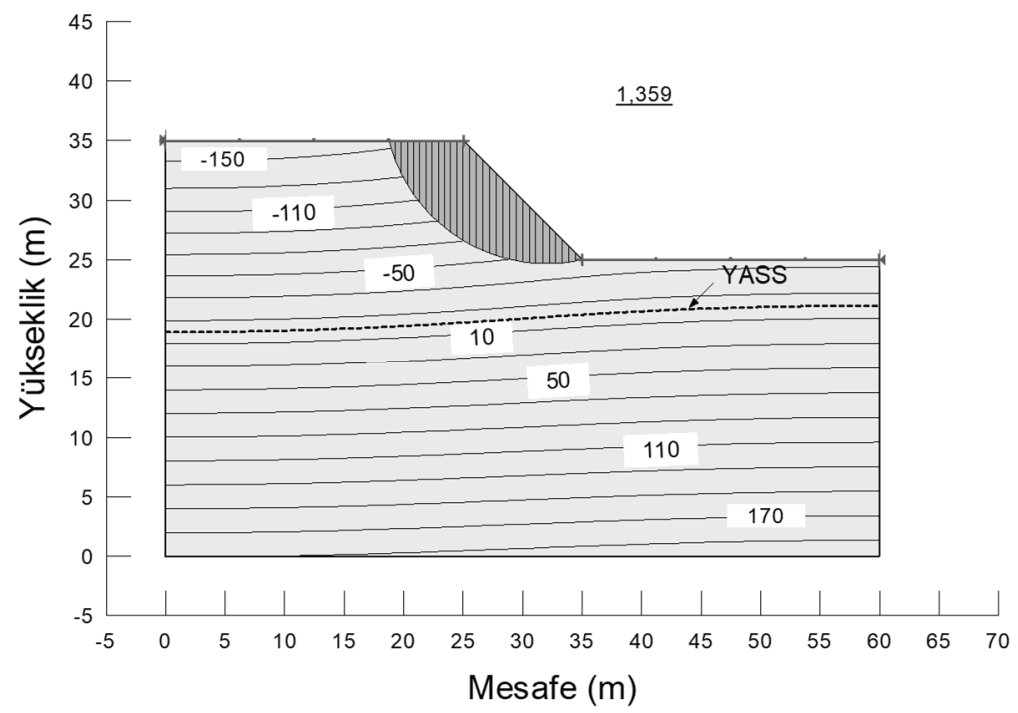

Şekil 18 - $45^{\circ}$ eğimli şevin 353 mm yağış sonrasında boşluk suyu basincı dăğllmı ve güvenlik saylsı

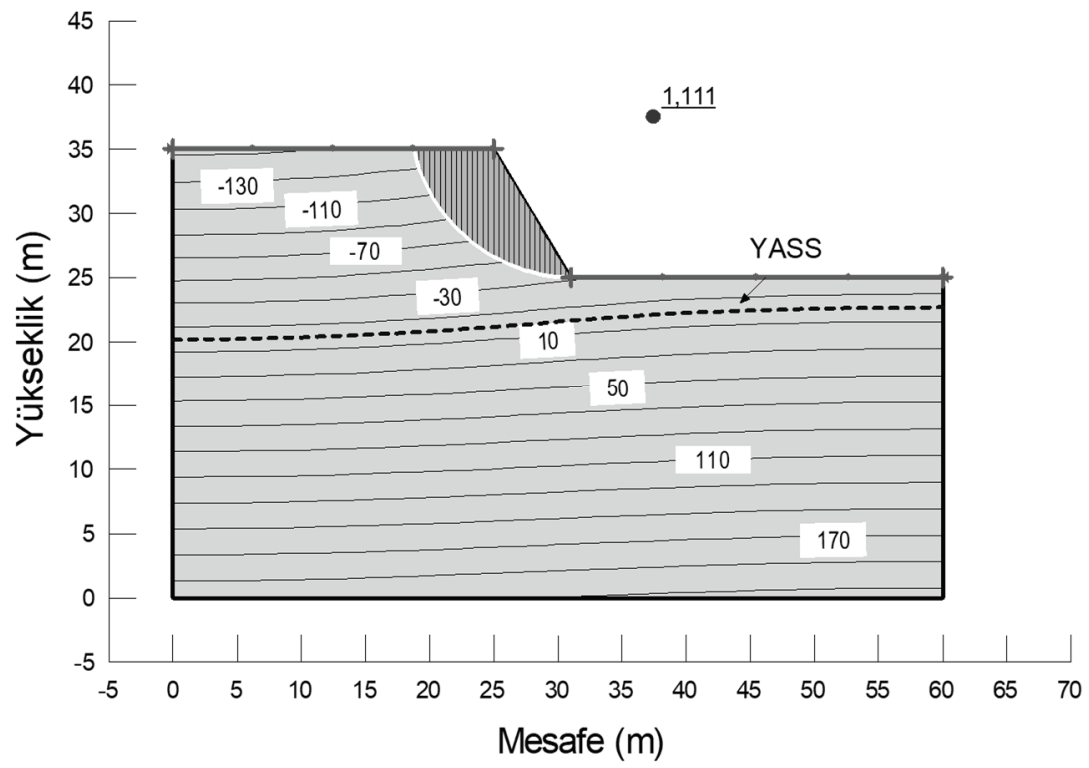

Şekil 19 - $60^{\circ}$ eğimli şevin 353 mm yağış sonrasında boşluk suyu basıncı dă̆ılımı ve güvenlik saylsı 
Eğime bağlı olarak başlangıç güvenlik sayılarında farklılık olduğu görülmektedir. Yağış sonrasında yapılan analizlere göre, farklı eğimlerdeki şevlerin güvenlik sayılarında meydana gelen değişim Şekil 20'de görülmektedir. Farklı eğimlerdeki üç şevin güvenlik sayılarında benzer oranda azalma görülmüştür. Buna göre şev eğiminin başlangıç güvenlik sayısında etkili olduğu fakat sonrasında ise duraysızlığın sızmaya bağlı olarak geliştiği ve güvenlik sayısında meydana gelen azalma miktarlarının tüm eğimler için birbirine oldukça yakın olduğu görülmektedir. Bu durum sızma ve yağış özellikleri ile buna bağlı olarak zemin dayanım parametrelerinin değişiminin şev eğiminden daha fazla etkin olduğunu göstermektedir. Nitekim Şekil 17-18-19'da farklı eğimler için yapılan sızma analizleri sonucunda elde edilen matrik emme dağılımlarının şev eğiminden çok etkilenmediği görülmektedir.

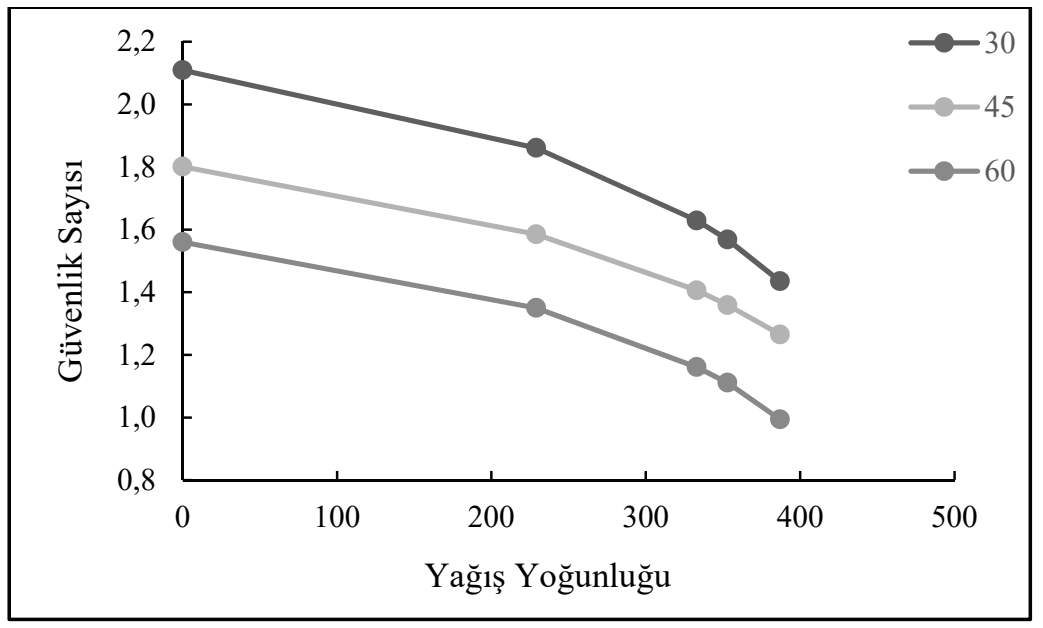

Şekil 20 - Şev eğimine bă̆lı olarak yă̆lş etkisinde güvenlik sayılarının değişsimi

\section{SONUÇLAR}

Yamaçlar ve kompaksiyon ile oluşturulan şevlerin çoğu doygun olmayan zeminler kategorisinde yer alırlar. Doygun olmayan zeminlerde, belirli koşullara sahip (zemin hidrolik geçirgenliği, yağış düzeyi vb.) bir şevin duraylılığı üzerinde, yağış oldukça etkili bir faktör olabilmektedir. Yağış öncesi duraylı olan bazı şevler, yağış sonrasında mukavemetini kaybedip göçebilmektedir. Özellikle uygun hidrolojik ve zemin koşullarının olduğu bölgelerde, şev duraylılığının araştırılmasında bu etkinin göz önüne alınması önem arz etmektedir.

Mevcut çalışma, yağış yoğunluğunun şev duraylılığını dikkate değer mertebede etkilediğini, yapılan analizlerle ortaya koymaktadır. Çalışma kapsamında incelenen bölgede, başlangıçta duraylı olan bir şevin belirli yoğunlukta bir yağışa maruz kalması sonucunda, güvenlik sayısının, şev göçmesinin meydana gelebileceği sınıra yaklaştı̆̆ı görülmektedir. Yapılan çalışmada, yağış yoğunluğu ile şev güvenlik sayısı arasında doğrusal olmayan, azalan bir ilişki olduğu gösterilmiştir. Bu ilişkinin, matrik emme ile hidrolik geçirgenlik arasındaki 
doğrusal olmayan ilişkiye bağlı olarak; yoğun yağış boyunca artan miktarda suyun zemine sızmasının ve buna bağlı olarak zemindeki negatif boşluk suyu basıncı ve kayma dayanımının doğrusal olmayan şekilde azalmasının sonucunda meydana geldiği değerlendirilmektedir.

Yağış süresinin sızma ve buna bağlı olarak şev duraylılığına olan etkileri incelendiğinde, kısa süreli görece yoğun yağışların; uzun süreli fakat görece daha düşük yoğunluklu yağışlar kadar etkili olabileceği görülmüştür.

Doygun olmayan koşullarda yağış etkisinde, ara geçirgenliğe sahip bir şevin güvenlik sayısındaki azalmanın, sızma-drenaj dengesinin boşluksuyu basıncı dağılımında meydana getirdiği değişimin büyüklüğü ile ilgili olduğu görülmüştür. Çalışma kapsamında incelenen ara geçirgenliğe sahip zeminde sızma-drenaj dengesinin belirleyici olduğu ve geçirgenlik azaldıkça duraylılığın düştüğü görülmektedir. İncelenen zeminin ara geçirgenliğe sahip olması, zeminin boşluksuyu basınçlarının yağıştan daha fazla etkilenmesine ve güvenlik sayısının daha geniş bir aralıkta değişmesine ve mevcut zeminde yağış sonrası görülen duraysızlıklara da açıklık getirmektedir.

Şev eğiminin etkisi incelendiğinde, eğimin başlangıç güvenlik sayısını etkilediği, fakat yağışa bağlı olarak meydana gelen güvenlik sayısındaki azalmada yağış ve sızma özelliklerinin daha etkin olduğu görülmektedir.

\section{Semboller}

$\begin{array}{ll}\text { a } & \text { : şekil katsayısı } \\ \text { c' } & \text { : efektif kohezyon } \\ \text { c } & \text { : total kohezyon } \\ \text { I } & \text { : yağış yoğunluğu } \\ \mathrm{I}_{\text {min }} & : \text { minimum yağış yoğunluğu } \\ \mathrm{k}_{\mathrm{s}} & \text { : zeminin doygun haldeki geçirimliliği } \\ \mathrm{m} & : \text { şekil katsayısı } \\ \mathrm{n} & : \text { şekil katsayısı } \\ \mathrm{T} & : \text { yağış süresi } \\ \mathrm{T}_{\text {min }} & : \text { minimum yağış süresini } \\ \mathrm{V} & : \text { sızma oranı } \\ \mathrm{Z}_{\mathrm{w}} & : \text { derinlik } \\ \Theta & : \text { hacimsel su içeriğini, } \\ \Theta_{\mathrm{r}} & : \text { rezidüel hacimsel su içeriği } \\ \Theta_{\mathrm{s}} & : \text { doygun hacimsel su içeriği } \\ \phi & : \text { efektif içsel sürtünme açısı }\end{array}$




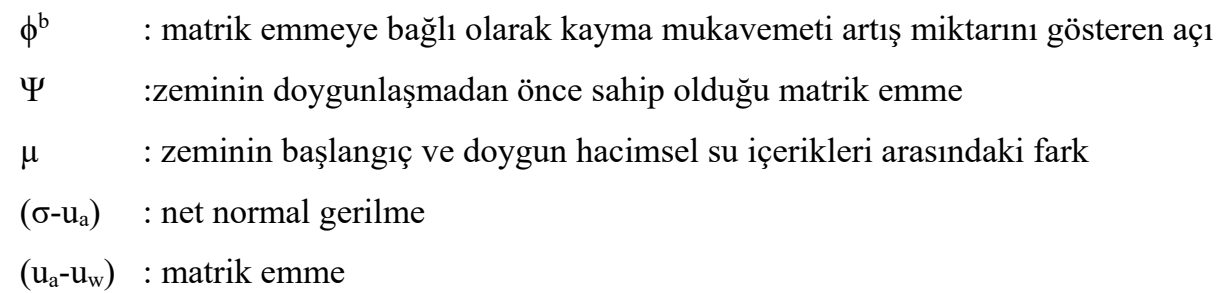

\section{Teşekkür}

MÜHENDÍSLİK.16.003 No'lu Bilimsel Araştırma Projesi kapsamında, çalışmaya olan katkılarından dolayı DÜBAP' a, verdiği desteklerden dolayı Karayolları 9. Bölge Müdürü Şefik SOLMAZ’a teşekkür ederiz.

\section{Kaynaklar}

[1] Ng, C. W. W., Shi, Q., A Numerical Investigation of the Stability of Unsaturated Soil Slopes Subjected to Transient Seepage. Computers and Geotechnics, 22 (1), 1-28, 1998.

[2] Oh, S., Lu, N., Slope Stability Analysis under Unsaturated Conditions: Case Studies of Rainfall-Induced Failure of Cut Slopes. Engineering Geology, 184, 96-103, 2015.

[3] Oh, W.T., Vanapalli, S. K., Influence of rain infiltration on the stability of compacted soil slopes. Computers and Geotechnics, 37, 649-657, 2010.

[4] Kim, J., Park, S., Jeong, S., Effect of Wetting Front Suction Loss on Stability of Unsaturated Soil Slopes. Seepage and Enviromental Geotechnics/ASCE, 148, 70-77, 2006.

[5] Cho, S.E., Lee, S.R., Evaluation of Surficial Stability for Homogeneous Slopes Considering Rainfall Characteristics. Journal of Geotechnical and Geoenvironmental Engineering, 128(9), 756-763, 2002.

[6] Richards, B.G., Measurement of the Free Energy of Soil Moisture by the Psychometric Technique Using Thermistors, in Moisutre Equilibria and Moisture Changes in Soils Beneath Covered Areas. A Symp. in Print, Australia: Butterworths, 1965.

[7] Fredlund, D.G., Morgenstern, N.R., Stress State Variables for Unsaturated Soils. Journal of the Geotechnical Engineering Division/ASCE, 103(GT5), 447-466, 1977.

[8] Leong, E.C., Rahardjo, H., Permeability Functions for Unsaturated Soils. Journal of the Geotechnical Engineering Division/ASCE, 123(12), 1118-1126, 1997.

[9] Fredlund, D.G. ve Rahardjo, H.. Soil Mechanics for Unsaturated Soils, John Wiley \& Sons, Inc, USA, 1993.

[10] Williams, J.R., Ouyang Y, Chen J.S., Estimation of Infiltration Rate in Vadose Zone: Application of Selected Mathematical Models. United States Environmental Protection Agency, EPA/600/R-97/128b, Vol. II, 1998. 
[11] Pradel, D., Raad, G., Effect of Permeability on Surficial Stability of Homogeneous Slopes. Journal of Geotechnical Engineering/ASCE, 119(2), 315-332, 1993.

[12] Fredlund, D.G., Morgenstern, N.R, Widger R.A., Shear Strength of Unsaturated Soils. Canadian Geotechnical Journal, 15(3), 313-321, 1978.

[13] Escario, V., Saez, J., The Shear Strength of Partly Saturated Soils, Geotechnique, 36(3), 453-456, 1986.

[14] Gan, J. K. M, Fredlund D. G., Rahardjo, H., Determination of the Shear Strength Parameters of an Unsaturated Soil Using the Direct Shear Test. Canadian Geotechnical Journal, 25, 500-510, 1988.

[15] Abramento, M., Carvalho, C.S., Geoetechnical Parameters for the Study of Natural Slopes Instabilization at Serra do Mar-Brazilian Southeast. Proceedings of the Twelfth International Conference on Soil Mechanics and Foundation Engg., Rio de Janerio, 1989.

[16] Vanapalli, S.K., Fredlund, D.G., Pufahl, D.E., Clifton, A.W., Model for the Prediction of Shear Strength with Respect to Soil Suction. Canadian Geotechnical Journal, 33, 379-392, 1996.

[17] TSE, TS 1900-1, İnşaat Mühendisliğinde Zemin Laboratuvar Deneyleri-Bölüm 1: Fiziksel Özelliklerin Tayini. TSE yayını, Ankara, 2006.

[18] ASTM D5298-94. Standard Test Method for Measurement of Soil Potential (Suction) Using Filter Paper, American Society of Testing and Materials. Annual Book of ASTM Standards, 1998.

[19] Russam, K., An Investigation into the Soil Moisture Conditions Under Roads in Trinidad, B.W.I. Geotechnique, 8: 55-71, 1958.

[20] Croney, D., Coleman, J.D., Pore Pressure and Suction in Soil. Conference on Pore Pressure and Suction in Soils, Londra, 1961.

[21] Van Genuchten, M. T., A Closed form Equation for Predicting the Water Permeability of Unsaturated Soils. Soil Sci. Soc. Am. J., 44, 892-898, 1980.

[22] Nishimura T, Toyota H, Vanapalli SK, Oh WT. Evaluation of Critical State Parameters for an Unsaturated Soil. In: Proceedings of the 60th Canadian Geotechnical Conference, Ottawa, 2007.

[23] Vanapalli SK, Fredlund DG, Pufahl DE., The Relationship Between the Soil-Water Characteristic Curve and the Unsaturated Shear Strength of a Compacted Glacial Till, Geotech Test J, 19(3), 259-68, 1996.

[24] Wang Q, Pufahl DE, Fredlund DG., A Study of Critical State on an Unsaturated Silty Soil. Canadian Geotechnical Journal, 39(1), 213-8, 2002. 